AperTO - Archivio Istituzionale Open Access dell'Università di Torino

\title{
Application of Ti-in-zircon and Zr-in-rutile thermometers to constrain high-temperature metamorphism in eclogites from the Dabie orogen, central China
}

\section{This is the author's manuscript}

Original Citation:

Availability:

This version is available http://hdl.handle.net/2318/142443

since 2016-06-01T15:44:21Z

Published version:

DOI:10.1016/j.gr.2013.10.011

Terms of use:

Open Access

Anyone can freely access the full text of works made available as "Open Access". Works made available under a Creative Commons license can be used according to the terms and conditions of said license. Use of all other works requires consent of the right holder (author or publisher) if not exempted from copyright protection by the applicable law. 


\section{(4) \\ UNIVERSITÀ DEGLI STUDI DI TORINO}

This Accepted Author Manuscript (AAM) is copyrighted and published by Elsevier. It is posted here by agreement between Elsevier and the University of Turin. Changes resulting from the publishing process - such as editing, corrections, structural formatting, and other quality control mechanisms may not be reflected in this version of the text. The definitive version of the text was subsequently published in [Liu Y.C., Deng L.P., Gu X.F, Groppo C. \& Rolfo F. (2015): Application of Ti-in-zircon and $\mathrm{Zr}$-in-rutile thermometers to constrain high-temperature metamorphism in eclogites from the Dabie orogen, central China. Gondwana Research, 27, 410-423, http://dx.doi.org/10.1016/j.gr.2013.10.011].

You may download, copy and otherwise use the AAM for non-commercial purposes provided that your license is limited by the following restrictions:

(1) You may use this AAM for non-commercial purposes only under the terms of the CC-BY-NC-ND license.

(2) The integrity of the work and identification of the author, copyright owner, and publisher must be preserved in any copy.

(3) You must attribute this AAM in the following format: Creative Commons BY-NC-ND license (http://creativecommons.org/licenses/by-nc-nd/4.0/deed.en), [+ Digital Object Identifier link to the published journal article on Elsevier's ScienceDirect ${ }^{\circledR}$ platform] 
Application of Ti-in-zircon and $\mathrm{Zr}$-in-rutile thermometers to

2

3

\section{granulitized eclogites from the Dabie orogen, central China}

4

5

6

7

${ }^{a}$ CAS Key Laboratory of Crust-Mantle Materials and Environments, School of Earth and Space Sciences, University of Science and Technology of China, Hefei 230026, China

${ }^{\mathrm{b}}$ Department of Earth Sciences, University of Torino, Via Valperga Caluso 35, 1-10125 Torino, Italy

${ }^{\text {c }}$ C.N.R. - I.G.G., Section of Torino, Via Valperga Caluso 35, 1-10125 Torino, Italy 2 (1) (4) 5 (1)

*Corresponding author. Tel./fax: +86 5513600367.

E-mail address: liuyc@ustc.edu.cn (Y.-C. Liu) 


\begin{abstract}
Granulitized eclogites from the Dabie orogen, central China represent deeply subducted mafic lower continental crust of the South China Block and record a complex polymetamorphic evolution during Triassic continental deep subduction and subsequent exhumation. These eclogites were strongly affected by multiple decompression and re-crystallization processes during multistage exhumation, thus making the determination of peak metamorphic conditions particularly challenging. However, the recently calibrated Ti-in-zircon and Zr-in-rutile thermometers provide new tools to estimate the peak and post-peak temperatures. The obtained results suggest that the eclogites experienced a protracted high- $T\left(>900{ }^{\circ} \mathrm{C}\right)$ metamorphic evolution from high-T/ultrahigh-pressure (UHP) eclogite-facies to UHT/HP granulite-facies conditions, characterized by near-isothermal decompression during the initial stages of exhumation.
\end{abstract}

Most of the analyzed zircons contain less than $20 \mathrm{ppm}$ Ti and only $5-10 \%$ of them contain up to $60-100 \mathrm{ppm} \mathrm{Ti}$, the latter corresponding to metamorphic temperatures of $>900{ }^{\circ} \mathrm{C}$. The occurrence of decompression textures preserved in robust minerals (e.g., low-Na omphacite inclusions coexisting with quartz, rutile and ilmenite in zircon; clinopyroxene + plagioclase + quartz intergrowths after omphacite in garnet) suggests that, even in robust minerals such as zircon, mineral inclusions may have experienced some degrees of decompression breakdown or retrogression. Therefore, Ti concentrations in zircons and $\mathrm{Zr}$ concentrations in rutile grains within garnet and zircon, respectively, may have been strongly modified by re-crystallization or re-equilibration. As a result, only few (5-10\%) zircons record their actual crystallization temperatures. In comparison, the rutile inclusions in zircon generally define higher temperatures, likely corresponding to their formation and preservation in a Zr-saturated environment. We therefore suggest that rutile inclusions in zircon are the most suitable candidates for high-grade $T$ estimates, especially in strongly retrogressed eclogites.

This study also provides thermometric evidence that supports the previously 


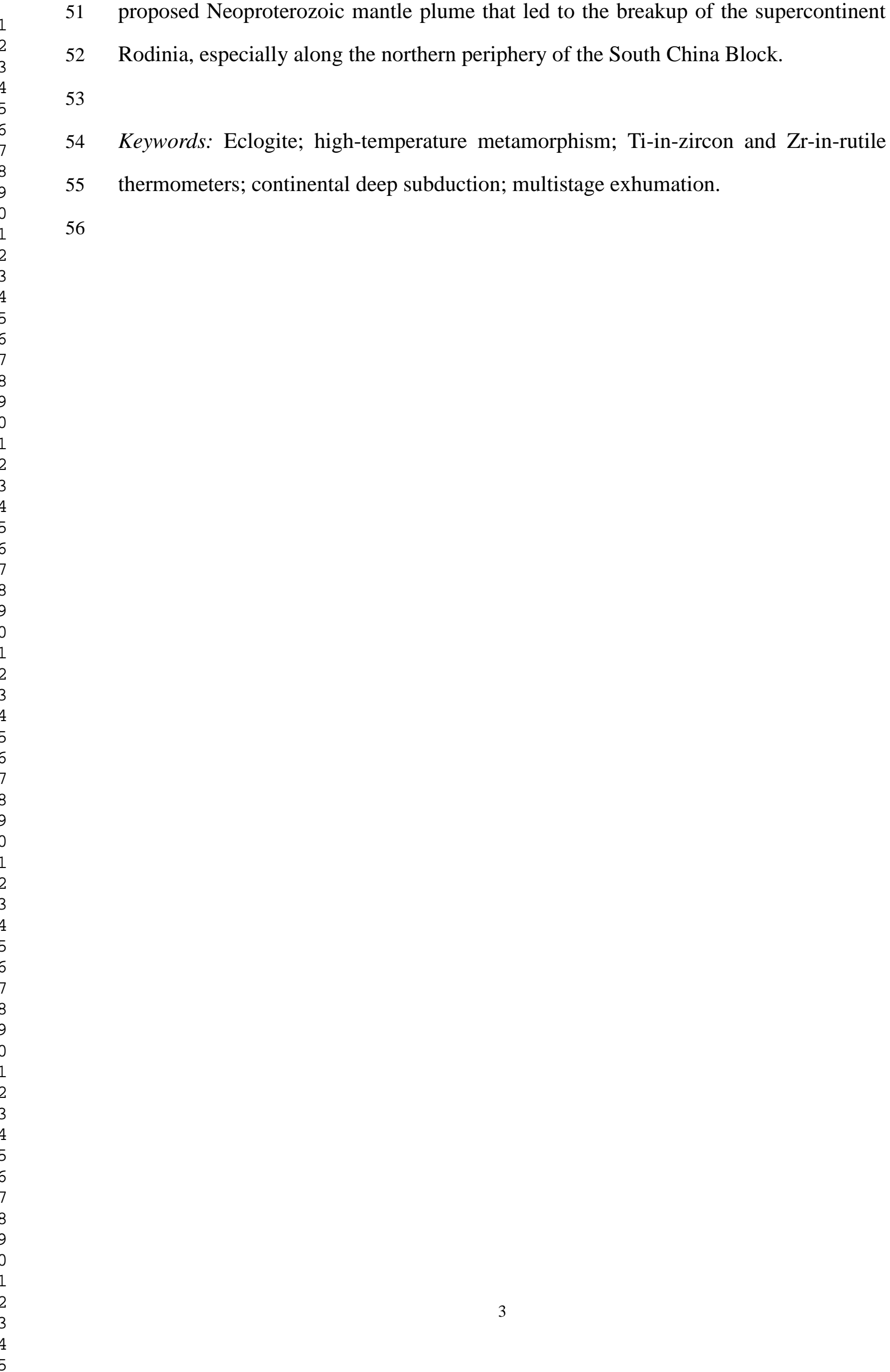




\section{Introduction}

Peak and post-peak temperature estimates are crucial for better understanding the genesis and evolution of high-pressure (HP) and ultrahigh-pressure (UHP) eclogites and related metamorphic rocks in subduction zones. However, this task is challenging when investigating high-grade rocks, particularly those formed under extreme metamorphic conditions such as ultrahigh-temperature (UHT) metamorphism (Harley, 1998, 2008; Brown, 2007; Kelsey, 2008; Santosh and Kusky, 2010). Temperatures of $>900{ }^{\circ} \mathrm{C}$ are, in fact, higher than the closure temperature of most conventional thermometers (Baldwin et al., 2007). An accurate estimate of peak temperature for high-grade rocks is often hampered by the significant re-equilibration or re-crystallization during retrogression and cooling. This has led to the recent development of trace-element thermometers such as those based on titanium concentration in zircon and zirconium concentration in rutile, which may provide a more precise link between the $P-T$ path and geochronological data (e.g., Watson and Harrison, 2005; Watson et al., 2006; Timms et al., 2011). Since their earlier development, the new Ti-in-zircon and Zr-in-rutile thermometers (Zack et al., 2004; Watson et al., 2006; Ferry and Watson, 2007; Baldwin et al., 2007; Tomkins et al., 2007) have been more and more successfully used to estimate the peak and post-peak temperatures of polymetamorphic rocks (e.g., Zack and Luvizotto, 2006; Spear et al., 2006; Baldwin et al., 2007; Miller et al., 2007; Tomkins et al., 2007; Chen and Li, 2008; Liu et al., 2010a; Zhang et al., 2010; Jiao et al., 2011; Meyer et al., 2011; Zheng et al., 2011; Kooijman et al., 2012; Ewing et al., 2013).

Zircon and rutile are common accessory minerals in metamorphic rocks. Therefore, although the possibility of diffusive resetting at high temperature may complicate the interpretation of apparent temperatures and zoning profiles (Watson et al., 2006), Ti-in-zircon and Zr-in-rutile thermometers may allow precise temperature estimates of metamorphism (Zack et al., 2004; Spear et al., 2006; Watson et al., 2006; Baldwin et al., 2007; Ferry and Watson, 2007; Page et al., 2007; Tomkins et al., 2007). Zircon is a robust mineral (Dobrzhinetskaya et al., 2003; Watson et al., 2006) and is 
extensively used for $\mathrm{U}-\mathrm{Pb}$ geochronology, giving useful information about a wide range of tectonic events and related processes (e.g., Rubatto et al., 1999; Hermann et al., 2001; Möller et al., 2002; Liu et al., 2011a). Furthermore, the Ti-in-zircon thermometer has the potential to create an invaluable link between $\mathrm{U}-\mathrm{Pb}$ ages and temperatures measured in-situ in zircon (e.g., Baldwin and Brown, 2008): this is particularly true for multiple metamorphic rocks, because internal fine-scaled growth structures in zircon may be directly correlated with variations in the physicochemical conditions and the duration of each metamorphic event (e.g., Rubatto et al., 1999; Corfu et al., 2003; Whitehouse and Platt, 2003). Application of this thermometer to two typical UHT granulite localities demonstrated that it is a powerful method to determine the peak temperatures of zircons (Baldwin et al., 2007). However, there are also studies that show zircon re-crystallized post-peak and did not preserve UHT temperatures, whereas rutile in the same samples did (Ewing et al., 2013).

Zr-in-rutile thermometry, based on the $\mathrm{Zr}$ content in rutile coexisting with quartz and zircon, is an alternative and complementary method for estimating temperature of metamorphism, especially useful for eclogites. Earlier calibrations of the Zr-in-rutile thermometer focused on the strong effect of temperature (Zack et al., 2004; Watson et al., 2006; Ferry and Watson, 2007), without including a correction for pressure. The pressure dependence was incorporated into this thermometer with the calibration of Tomkins et al. (2007). This revised thermometer has been demonstrated to be a reliable method for the estimate of the peak temperatures in UHT rocks (e.g., Jiao et al., 2011; Meyer et al., 2011; Kooijman et al., 2012). Also, Luvizotto and Zack (2009) obtained Zr-in-rutile temperatures of up to $850-930{ }^{\circ} \mathrm{C}$ for rutile from granulite facies metapelites from Val Strona and Val d'Ossola, but with significant resetting of Zr-in-rutile temperatures to a spread of lower values.

As a result, a combined Ti-in-zircon and Zr-in-rutile thermometry is required to constrain peak and post-peak metamorphic temperatures for eclogites and related high-grade rocks involved in complex processes. A suitable lithology to usefully apply these two novel techniques is the granulitized eclogites of the Luotian dome in the southwestern part of the North Dabie complex zone (NDZ), central China, which is a 
portion of deeply subducted mafic lower continental crust of the South China Block (Liu et al., 2007a). The eclogites underwent UHP and HP eclogite-facies metamorphism, followed by HP granulite-facies overprint and later amphibolite-facies retrogression, during continental subduction and exhumation (Liu et al., 2011b). The peak metamorphic assemblages and compositions of such UHP rocks are commonly obliterated or overprinted by subsequent retrograde metamorphism at UHT $\left(905-917{ }^{\circ} \mathrm{C}\right.$ ) conditions (Liu et al., 2011b). These metamorphic temperatures approximated or exceeded the closure temperatures of the $\mathrm{Fe}-\mathrm{Mg}$ exchange thermometer between garnet and clinopyroxene (e.g., Raheim and Green, 1974; Baldwin et al., 2007). In this context, it is generally difficult, using conventional geothermometers, to precisely constrain the actual metamorphic temperatures experienced by the eclogites during the various stages of their evolution; nevertheless this information is essential for a robust understanding of the genetic and evolutionary processes of the UHP rocks in the NDZ.

Zircon is extremely robust to thermal disturbance and its $\mathrm{U}-\mathrm{Pb}$ and REE systematics can remain preserved despite multiple (U)HT metamorphic episodes and re-equilibration, thus providing reliable ages and genetic information (Kooijman et al., 2011; and references therein). Although the NDZ eclogites experienced a complex metamorphic evolution and multistage retrograde overprinting, zircons from the eclogites still preserve multiple metamorphic age-records with REE and mineral inclusion constraints (Liu et al., 2011a). Combining the zircon U-Pb ages and the estimated temperatures and pressures, the whole $P-T-t$ path of the eclogites during subduction and exhumation may be therefore constrained in detail. In this study, we applied Ti-in-zircon and Zr-in-rutile thermometers to the NDZ granulitized eclogites. The results provide unambiguous evidence of a multistage high- $T$ evolution in the NDZ. In addition, the applicability of the zircon and rutile thermometers to granulitized eclogites is tested. The implications of our results on the $P-T-t$ evolution of the NDZ are discussed, shedding new light on the formation and exhumation of the UHP metamorphic belt in the Dabie orogen. 


\section{Geological setting}

The Dabie orogen is a well known UHP terrain, located in the intermediate segment of the Qinling-Dabie-Sulu orogenic belt formed by the Triassic continental collision between the North China Block and South China Block. It comprises several fault-bounded terranes with varying metamorphic grades and evolutional histories, and is subdivided into five major lithotectonic units from north to south (Xu et al., 2003; Liu et al. 2007a): (1) the Beihuaiyang zone (BZ); (2) the North Dabie complex zone (NDZ); (3) the Central Dabie UHP metamorphic zone (CDZ); (4) the South Dabie low-T eclogite zone (SDZ); and (5) the Susong complex zone (SZ) (Fig. 1). These zones are separated by the Xiaotian-Mozitan fault, Wuhe-Shuihou fault, Hualiangting-Mituo fault and Taihu-Shanlong fault, respectively. Zone (1) is a low-grade composite unit comprising the Foziling (or Xinyang) Group and the Luzhenguan (or Guishan) complex, whereas Zones (2), (3), (4) and (5) belong to the subducted South China Block (Xu et al., 2003, 2005; Liu et al., 2005, 2007a, 2010b, 2011a; Liu and Li, 2008).

A variety of UHP metamorphic rocks, including eclogite, gneiss, quartz jadeitite, schist and impure marble with eclogite nodules, occur in the CDZ and SDZ (e.g., Xu et al., 1992; Okay, 1993; Okay et al., 1993; Rolfo et al., 2004; Li et al., 2004). The occurrence of diamond and coesite in the metamorphic rocks from the CDZ indicates that the UHP metamorphism occurred at $700-850{ }^{\circ} \mathrm{C}$ and $>2.8 \mathrm{GPa}$ (e.g., Okay et al., 1989; Wang et al., 1989; Xu et al., 1992; Okay, 1993; Rolfo et al., 2004), whereas the peak $P-T$ conditions of the eclogites in the SDZ were estimated at $670{ }^{\circ} \mathrm{C}$ and 3.3 GPa (Li et al., 2004). In both the CDZ and SDZ units the UHP eclogite-facies stage was followed by HP eclogite- and amphibolite-facies retrograde metamorphism (e.g., Xu et al., 1992; Rolfo et al., 2004; Li et al., 2004).

The NDZ mainly consists of tonalitic and granitic orthgneisses and post-collisional intrusions with subordinate meta-peridotite (including dunite, harzburgite and lherzolite), garnet pyroxenite, garnet-bearing amphibolite, granulite and eclogite. The oriented mineral exsolutions in garnet and clinopyroxene, and the 
occurrence of micro-diamond imply that the NDZ eclogites underwent UHP metamorphism at $P$ > 3.5 GPa (Xu et al., 2003, 2005; Liu et al., 2005; Malaspina et al., 2006). The Triassic zircon U-Pb ages (Liu et al., 2000, 2007a, 2011a; Wang et al., 2012) and Sm-Nd ages (Liu et al., 2005) of the eclogites from the NDZ suggest that these rocks formed by the Triassic subduction of the South China Block, similarly to those from the CDZ and SDZ. The Triassic metamorphic ages (Liu et al., 2000, 2007b; Xie et al., 2010) and the occurrence of micro-diamond in zircon and garnet (Liu et al., 2007b) from the NDZ banded gneisses suggest that also the gneisses hosting the eclogites were involved in the deep subduction of the South China Block, thus implying that the NDZ experienced UHP metamorphism as a coherent unit. After the UHP and HP eclogite facies metamorphism, the NDZ eclogites experienced granulite-facies overprinting and later amphibolite-facies retrogression (e.g., Xu et al., 2000; Liu et al., 2001, 2005, 2007a). This corroborates the case for a distinct evolution in the different slices of the Dabie UHP belt. That is, although the three eclogite-bearing units, i.e. the SDZ, CDZ and NDZ, all experienced UHP metamorphism, they had different exhumation histories, suggesting that they represent decoupled UHP slices and most probably represent different levels of crustal rocks (see Liu and Li, 2008 for a review).

The Luotian dome in the southwestern segment of the NDZ is a deeply eroded area with both felsic and mafic granulite lenses (Chen et al., 1998, 2006; Liu et al., 2007a; Wu et al., 2008). The eclogite occurs as lenses or blocks in garnet-bearing granitic migmatitic orthogneiss (Liu et al., 2007a). They preserve early granulite-facies mineral relics and have been overprinted by regionally pervasive HP granulite-facies metamorphism, followed by penetrative amphibolite-facies retrogression during exhumation. The eclogite-facies assemblage consists of garnet and relict omphacite, with rutile, quartz, allanite and fluoro-apatite as common additional constituents. Although the precise time-temperature cooling history is still not well-known in detail, the studies by Liu et al. (2007a, 2011b) showed that the NDZ underwent a complex multistage evolution characterized by a nearly isothermal decompression during the early stages of exhumation. In particular, five metamorphic 
stages have been recognized for the eclogites in the Luotian dome area (Liu et al., 2007a, 2011b): (1) granulite-facies stage, suggested by the occurrence of hypersthene, plagioclase and diopside inclusions within garnet and/or by Neoproterozoic metamorphic zircon (Liu et al., 2007a); (2) UHP coesite/diamond eclogite-facies stage at $\mathrm{P} \sim 4.0 \mathrm{GPa}$, suggested by the occurrence of diamond (Xu et al., 2003, 2005; Liu et al., 2007b) and coesite (Liu et al., 2011b); (3) HP quartz eclogite-facies stage, characterized by the coexistence of garnet, jadeite-poor omphacite and rutile with quartz instead of coesite; (4) granulite-facies retrogression stage, indicated by the presence of hypersthene, plagioclase and diopside symplectite after Na-clinopyroxene; (5) amphibolites-facies retrograde stage, documented by the widespread growth of amphibole. However, P-T conditions, especially temperatures for different stages have not been better constrained because of multiple decompression and re-crystallization processes as mentioned above.

\section{Sample descriptions}

The investigated samples were collected from Banchuanshan (samples LT9 and LT10), Luotian (sample 03LT1-1), Jinjiapu (samples 06LT3-2 and 09LT1) and Shiqiaopu (samples 07LT6-1 and 09LT2), respectively (Fig. 1). They can roughly be divided into two groups based on zircon typologies: the first eclogite type (Type 1; samples 03LT1-1, 06LT3-2, 07LT6-1, 09LT1 and 09LT2) contains almost homogeneous Triassic metamorphic zircons with rare or even no Neoproterozoic zircon cores (Liu et al., 2011a; Gu, 2012), whereas the second type (Type 2; samples LT9 and LT10) contains Neoproterozoic igneous and metamorphic zircon cores with rare Triassic metamorphic overgrowth rims (Liu et al., 2007a).

The detailed ages of the samples LT9, LT10, 03LT1-1, 06LT3-2, 07LT6-1 and 09LT2 were reported in Liu et al. (2007a, 2011a) and Gu (2012), respectively (see also Table 2). Based on previous investigations (Liu et al., 2011a; Gu, 2012), by CL images, inclusion assemblages, REE patterns and ages, the metamorphic/metamorphosed zircons from samples of the Type 1 eclogites can be 
234 subdivided into two episodes of mantle domains (called inner- and outer-mantles, named as M1 and M2) with distinct age-records of 230-220 Ma and 220-210 Ma,

236 cluster at $226 \pm 2 \mathrm{Ma}$ and $214 \pm 2 \mathrm{Ma}$, respectively. These two zircon domains grew 237 in distinct stages of the eclogites metamorphic evolution because they show UHP and 238 HP eclogite-facies signatures of Ca-rich garnet + omphacite $(\mathrm{Jd}=40-50)+$ coesite + 239 rutile and Mn-rich garnet + omphacite $(\mathrm{Jd}=20-30)+$ quartz + rutile, respectively 240 (Liu et al., 2011a; Gu, 2012). Rare thin overgrowth rims of 209-207 Ma and 200-190 241 Ma, formed at granulite- and amphibolite-facies stages, respectively, are locally 242 observed in zircon.

Details of the petrography and mineral chemistry of the eclogites were given in Liu et al. (2007a, 2011b) and are only summarized here. Samples LT9 and LT10 consist of garnet, omphacite and rutile and retrograde quartz, diopside, hypersthene, hornblende, plagioclase and ilmenite. Sample 03LT1-1 is a strongly retrogressed eclogite, mainly consisting of garnet, rutile, hornblende and plagioclase with minor quartz, diopside, hypersthene and ilmenite. Rare coesite in zircon and its pseudomorphs with radial fractures in garnet were observed (Liu et al., 2011b). The other eclogite samples (06LT3-2, 07LT6-1, 09LT1 and 09LT2) are less retrogressed and are composed of garnet, omphacite, diopside and rutile, with minor hypersthene, hornblende, plagioclase, quartz or its pseudomorphs after coesite and ilmenite. In all the samples, omphacite generally occurs as inclusion in garnet or zircon (Figs. 2a, b and 3). Two generations of omphacite may be distinguished on the basis of their $\mathrm{Na}_{2} \mathrm{O}$ contents, the earlier one being Na richer than the later generation (Fig. 4; Table 1). The later generation often coexists with quartz in zircon (Fig. 3b, f), suggesting a Si-rich precursor omphacite and is locally replaced by clinopyroxene + plagioclase + quartz intergrowths in garnet (Fig. 2d). In samples 07LT6-1 and 09LT2 omphacite inclusions within garnet and zircon are particularly abundant, and coesite pseudomorphs with radial fractures were locally observed within garnet (Figs. 2 and 3; Liu et al., 2011b). Furthermore, low-Na omphacite + quartz and rutile + ilmenite locally occur as coexisting or intergrowth inclusions in zircon (Figs. 3b, d, f, l and 5). 
264 strongly modified or broken down during multiple decompression and retrogression, also hampering the determination of peak $P-T$ conditions by conventional thermobarometry. Thus, in order to better constrain the metamorphic temperatures of UHP and HP eclogite-facies stages, the Ti-in-zircon thermometry and Zr-in-rutile thermometry on inclusions within zircon and garnet have been applied.

\section{Analytical methods}

Zircons were separated from the samples by crushing and sieving, followed by magnetic and heavy liquid separation and hand-picking under a binocular microscope. Representative zircon crystals were prepared for the CL investigations and in-situ $\mathrm{U}-\mathrm{Pb}$ dating and trace-element analyses. They, together with a zircon U-Pb standard TEM (417 Ma), were mounted in epoxy, which was then polished until all zircon grains were approximately cut in half. The internal zoning patterns of the crystals were observed by cathodoluminescence (CL) imaging at the Beijing SHRIMP Center and the Institute of Mineral Resources, Chinese Academy of Geological Sciences (CAGS) in Beijing. The representative CL images for the sample 07LT6-1 are presented in Fig. 3, and the remaining CL images were reported in Liu et al. (2007a, 2011a) and Gu (2012).

Mineral inclusions in zircon were identified using Raman spectroscopy at the Continental Dynamics Laboratory, CAGS in Beijing and the CAS Key Laboratory of Crust-Mantle Materials and Environments, University of Science and Technology of China in Hefei, and/or identified using the electron probe micro analyzer (EPMA) at the Institute of Mineral Resources, CAGS in Beijing. The analytical conditions of the Raman and EMPA were reported by Liu et al. (2009). Representative Raman spectra and compositions of mineral inclusions in zircon are reported in Fig. 5 and Table 1.

The rutile analyses were performed on a JEOL JXA-8230 EPMA at the Institute of Mineral Resources, CAGS in Beijing. Accelerating voltage was set at $20 \mathrm{kV}$ with $100 \mathrm{nA}$ beam current and 3-5 $\mu \mathrm{m}$ beam spot, counting times for $\mathrm{Zr}, \mathrm{Nb}, \mathrm{Cr}$ and $\mathrm{Fe}$ were 300, 400, 150 and 60 s, respectively. Spectroscopic crystals for Zr, Nb, Cr and 
Fe were PETH, PETJ, LIFJ and LIFJ, respectively (corresponding detection limits: 20, 27, 28 and 43 ppm). A $\mathrm{ZrO}_{2}$ standard was used to calibrate the peak position of $\mathrm{Zr}$, and a synthetic rutile was used to inspect the zero-concentration of $\mathrm{Zr}$ at the beginning, middle and at the end of each sequence. Analytical errors were about $\pm 15 \mathrm{ppm}$ at $1 \sigma$ according to counting statistics (Chen and Li, 2008). Optical and CL-images combined with back-scattered electron (BSE) images were used to select target areas devoid of cracks or inclusions other than rutile in zircon. Also, the BSE images were guided to determine the analyzed domains on rutile inclusions in garnet on the thin sections. Generally, larger rutile grains (> $3 \mu \mathrm{m}$ in diameter, mostly $5-10 \mu \mathrm{m}$ or more) were selected for spot analyses. If $\mathrm{SiO}_{2}$ contents were above 0.3 wt.\% the analysis was discarded as these data were probably influenced by nearby zircon grains (Zack et al., 2004). In addition, it has been shown (Boniface et al., 2012) that there are the lower $\mathrm{Zr}$ contents in matrix rutile compared to rutile inclusions in garnet, due to re-equilibration of the matrix grains during the late-stage mylonitization that affected the eclogites. So, we analyzed rutile inclusions in garnet and zircon from the samples.

The Ti contents in zircon from samples LT9, LT10, 03LT1-1, 06LT3-2 and 07LT6-1 were measured using laser ablation multi-collector inductively coupled plasma mass spectrometer (LA-MC-ICPMS) at Institute of Geology and Geophysics, the Chinese Academy of Sciences in Beijing. The detailed parameters of the instrument can be found in Jiao et al. (2011), and the analytical procedure was previously reported by Yuan et al. (2004). A Geolas-193 laser-ablation microprobe was attached to a Neptune multi-collector ICPMS. Typical ablation times were 30 to $90 \mathrm{~s}$ with a $10 \mathrm{~Hz}$ repetition rate and laser power of $100 \mathrm{~mJ} / \mathrm{pulse}$, resulting in a pit depth of 30 to $50 \mu \mathrm{m}$. The spot diameter for zircon was $32 \mu \mathrm{m}$.

\section{Results}

\subsection{Zr contents in rutile and Zr-in-rutile temperature estimates}

Calculation of Zr-in-rutile temperatures for rutile inclusions within zircon follows the pressure-dependent thermometer of Tomkins et al. (2007) at assumed 4.0 GPa and 
2.0 GPa for the UHP ( $\mathrm{M}_{1}$ domains) and $\mathrm{HP}\left(\mathrm{M}_{2}\right.$ domains $)$ eclogite-facies metamorphism, respectively and at $1.0 \mathrm{GPa}$ for the granulite-facies stage (rim domains) (Liu et al., 2011a; Gu, 2012). The estimation of Zr-in-rutile temperatures for rutile inclusions within garnet was made at $\mathrm{P}=4.0 \mathrm{GPa}$ and $2.0 \mathrm{GPa}$ for the UHP and HP eclogite-facies conditions, respectively. The $\mathrm{Zr}$ contents and calculated temperatures are listed in Tables 2 and 3 and depicted in Figs. 6 and 7.

Rutile inclusions in zircon mainly occur within mantle domains $\mathrm{M}_{1}$ and $\mathrm{M}_{2}$ of metamorphic/metamorphosed zircons, formed at UHP and HP eclogite-facies conditions, respectively, and a few in overgrowth rims formed at granulite-facies conditions. Zirconium concentrations in rutile within garnet and zircon are characterized by a large spread, varying from less than 900 to more than 4000 ppm, and defining a broad range of calculated temperatures from $<700$ to approximately $1100{ }^{\circ} \mathrm{C}$ (Figs. 6, 7). More in detail, the rutile inclusions located in inner-mantle domains $\left(\mathrm{M}_{1}\right)$ of zircon have the high $\mathrm{Zr}$ contents (1030-4310 ppm) and record a relatively narrow range of temperatures of $880-1080{ }^{\circ} \mathrm{C}$, mostly $936-1072{ }^{\circ} \mathrm{C}$ with an average value of $982{ }^{\circ} \mathrm{C}$. Rutile grains included in the outer-mantle domains $\left(\mathrm{M}_{2}\right)$ of zircon contain $\mathrm{Zr}$ contents of $800-5800 \mathrm{ppm}$ and define a wide range of temperatures (780-1030 ${ }^{\circ} \mathrm{C}$ ), a few $901-1028{ }^{\circ} \mathrm{C}$ with an average value of $946{ }^{\circ} \mathrm{C}$. A few rutile grains occurring in the rims of zircon give lower temperatures of $c .850{ }^{\circ} \mathrm{C}$ (Fig. 6). In contrast, rutile inclusions within garnet have relatively lower $\mathrm{Zr}$ contents of 100-800 ppm, yielding lower temperatures $\left(600-850{ }^{\circ} \mathrm{C}\right.$ at $\mathrm{P}=4.0 \mathrm{GPa}$ and $600-800{ }^{\circ} \mathrm{C}$ at $\mathrm{P}=$ 2.0 GPa; Fig. 6a and Table 3).

\subsection{Ti contents in zircon and Ti-in-zircon temperatures}

Ti-in-zircon temperatures were calculated following the experimental calibration of Watson et al. (2006). The results for $\mathrm{Ti}$ contents in zircon and calculated temperatures are listed in Tables 3 and 4 and presented in Figs. 8 and 9. Zircon grains in the three Type 1 eclogite samples consist of different domains among which inner (M1) and outer (M2) mantle domains formed at UHP and HP eclogite-facies conditions at $\sim 226 \mathrm{Ma}$ and $\sim 214 \mathrm{Ma}$, respectively. These UHP and HP domains have 
352 Ti contents of 2.15-97.8 ppm (Table 4), yielding Ti-in-zircon temperatures of $353620-990{ }^{\circ} \mathrm{C}$. Ti contents in the zircon rim domains are low ( $\left.<7 \mathrm{ppm}\right)$ and indicate a $T$ of $650-700{ }^{\circ} \mathrm{C}$, except for two granulite-facies overgrowth rims which yield a $T$ of 807-828 ${ }^{\circ} \mathrm{C}$ (Fig. 8). Thus, most of the calculated temperatures for different domains

\section{Discussion}

\subsection{Metamorphic temperatures at peak and post-peak stages}

The results of this study show that, although all the samples experienced the same metamorphic evolution, only $5-10 \%$ of the Triassic peak and post-peak metamorphic zircons from the Type 1 eclogites contain sufficient Ti concentrations to give high- $T$ conditions (Fig. 8). Temperatures higher than $900{ }^{\circ} \mathrm{C}$ are preserved only in one UHP and two HP eclogite-facies zircon domains (M1 and M2, respectively), whereas the majority of the analyzed zircons give temperatures of $650 \pm 50{ }^{\circ} \mathrm{C}$ (Fig. 8), probably indicating the amphibolite-facies re-equilibration/re-crystallization temperature of the Ti-in-zircon thermometer. 
The significant variability of $\mathrm{Zr}$ in rutile (Tables 2 and 3) and the resulting scatter in calculated temperatures (especially for rutile inclusions in garnet) (Fig. 6) are probably due to retrograde re-equilibration and/or to local fluid-mediated re-crystallization during retrogression owing to the occurrence of fractures in garnet (see Fig. 2c) (Meyer et al., 2011; Kooijman et al., 2012). As a consequence, results of the Zr-in-rutile thermometry should be treated with caution when dealing with high- $T$ rocks which have undergone pronounced retrogression. In comparison, Zr-in-rutile thermometry applied on rutile inclusions within zircon, especially those shielded in the inner- and outer-mantle domains of Triassic zircons, yields 900 to $\sim 1100{ }^{\circ} \mathrm{C}$.

The high temperature values of $900-1050{ }^{\circ} \mathrm{C}$ estimated by both the Ti-in-zircon and the Zr-in-rutile thermometers for the UHP metamorphic stage are consistent with the reported peak UHP temperatures of $900-960{ }^{\circ} \mathrm{C}$ (at $P=4.0 \mathrm{GPa}$ ) calculated using Grt-Cpx thermometry (Liu et al., 2007a). Only one inclusion of rutile was observed in the overgrowth rims of zircon and records temperatures of $820-850{ }^{\circ} \mathrm{C}$ (Fig. 6), similar to those estimated by Ti-in-zircon thermometry (granulite-facies overgrowth rims; Fig. 8).

The Zr-in-rutile and Ti-in-zircon thermometers combined with conventional thermometry demonstrate that the eclogites experienced a multistage high- $T$ (> $900{ }^{\circ} \mathrm{C}$ ) metamorphic evolution at UHP and HP eclogite-facies conditions, followed by granulite-facies overprinting at UHT conditions.

In addition, as to the two samples of the Type 2 eclogites, their Neoproterozoic magmatic and metamorphic zircon cores yield Ti-in-zircon temperatures of 670-1149 ${ }^{\circ} \mathrm{C}$ (Fig. 9) with temperatures mostly in the range of $670-800{ }^{\circ} \mathrm{C}$ and a few $>900{ }^{\circ} \mathrm{C}$. The highest temperature values of $>900{ }^{\circ} \mathrm{C}$ may be the closest to the real temperatures (Liu et al., 2010a), thus for the first time documenting a UHT metamorphism during the Neoproterozoic. In contrast, the lower temperatures might represent the result of re-equilibration as suggested by Timms et al. (2011).

\subsection{Factors affecting Ti-in-zircon and Zr-in-rutile temperature estimates}

\subsubsection{Ti-in-zircon thermometer}


Pre-existing zircon in rocks may re-equilibrate in response to changing $P-T$ conditions or fluid compositions (Kooijman et al., 2011). Timms et al. (2011) also suggested that the highest Ti-in-zircon temperatures recorded in zircon might represent only minimum estimates for primary zircon crystallization and that the lowest $\mathrm{Ti}$ concentrations might record re-equilibration. Our results are in agreement with this interpretation. The analyzed zircons from the NDZ eclogites, in fact, show a large spread of $\mathrm{Ti}$ concentrations thus defining a wide range of temperatures. These strongly variable calculated temperatures may result from two main factors: (i) they may correspond to different growth stages of zircon, as suggested by the multiple age-records (Liu et al., 2011a, b; Gu, 2012), and/or (ii) they may be related to significant re-equilibration processes. However, since zircon domains with different ages generally define homogeneous Ti-in-zircon temperatures of $650 \pm 50{ }^{\circ} \mathrm{C}$ with the exception of few high- $T$ values $>900{ }^{\circ} \mathrm{C}$ (Figs. 8 and 9), we suggest that the highest calculated temperatures may represent the $T$ of zircon growth/crystallization, while the lower temperatures probably represent the re-equilibration temperature at amphibolite-facies conditions, in agreement with those determined by conventional thermobarometry (Liu et al., 2007a) and with the lower temperatures derived from Zr-in-rutile thermometry (this study).

\subsubsection{Zr-in-rutile thermometer}

It has been documented that the Zr-in-rutile thermometer is very resistant to diffusion and re-equilibration even under UHT metamorphic conditions and can preserve peak metamorphic temperatures higher than most thermometers (e.g., Kooijman et al., 2012; Ewing et al., 2013; and references therein). Zack et al. (2004) argued that rutile included in mineral phases in which diffusivities are high (e.g. quartz, kyanite) generally show significant evidence of re-equilibration during cooling, whereas rutile inclusions in garnet generally preserve higher $\mathrm{Zr}$ contents than matrix rutile. However, conflicting evidence exists on this argument, since other studies (e.g., Baldwin et al., 2007) show little correlation between recorded Zr-in-rutile temperatures and the rutile being in the matrix or included in garnet. The diffusion 
441 data also suggest that Zr signatures of rutiles from UHT systems are likely to be lost 442 except under conditions of extremely rapid cooling (Cherniak et al., 2007). Thus, $\mathrm{Zr}$ 443 in rutile signatures from high- $T$ contexts may be only locally retained, depending on 444 the nature of surrounding materials and the effectiveness of diffusional transport through them (e.g., Zack et al., 2004; Watson et al., 2006).

In this study, the highest concentrations of $\mathrm{Zr}$ are systematically recorded in well shielded rutile inclusions within zircon, although numerous grains located in the same mantle and rim domains of zircon preserve low Zr concentrations as well (Figs. 6 and 7; Tables 2 and 3). Thus, being shielded in zircon is not a prerequisite for rutile to preserve high temperatures. In contrast, rutile inclusions in garnet have systematically lower Zr contents than those included in zircon (Fig. 6). Previous investigations (e.g., Jiao et al., 2011; Meyer et al., 2011; Triebold et al., 2011; Kooijman et al., 2012) clearly indicate that rutile grains with lower $\mathrm{Zr}$ concentrations have been likely affected by re-equilibration and/or re-crystallization processes, even if included in robust minerals such as garnet; in this case, the corresponding calculated temperatures are not representative of the metamorphic conditions of entrapment (see also Hermann and Rubatto, 2003). Although zircon is probably the best rigid host mineral, this study demonstrates that some rutile inclusions within zircon were transformed to ilmenite, thus suggesting that retrogression may affect also zircon and its inclusions (Fig. 3). It may be thus concluded that rutile grains with higher $\mathrm{Zr}$ concentrations (and corresponding calculated temperatures) should be the least affected by late resetting, most probably revealing rutile formation temperatures (Triebold et al., 2011), whereas the lower temperatures of $650-750{ }^{\circ} \mathrm{C}$ (Fig. 6) probably represent the closure temperature of the Zr-in-rutile thermometer (Cherniak et al., 2007) and/or re-equilibration/re-crystallization temperatures at amphibolites-facies conditions (Liu et al., 2007a).

\subsubsection{Late re-equilibration processes affecting rutile and zircon}

The widespread and homogeneous low- $T$ estimates of $650-750{ }^{\circ} \mathrm{C}$ obtained from both the Zr-in-rutile and Ti-in-zircon thermometers imply that both rutile and zircon 
471 from the studied NDZ eclogites were significantly affected by re-equilibration or re-crystallization processes during exhumation or decompression, as reported by Liu et al. (2009), Boniface et al. (2012) and Ewing et al. (2013). Moreover, the wide range of calculated temperatures obtained from both thermometers is interpreted to be the result of trace element exchange between rutile/zircon and the matrix, this process likely occurring at the grain-boundary scale or along the fracture and being controlled by fluid-mediated transport within very local domains.

Furthermore, Lucassen et al. (2010) showed that, in fluid-dominated natural systems, the diffusion coefficients of $\mathrm{Zr}$ and $\mathrm{Nb}$ in rutile could be higher than those determined experimentally. Luvizotto and Zack (2009) also argued that re-equilibration of $\mathrm{Zr}$ in rutile occurs by ion exchange with neighboring minerals in a fluid-present system, whereas in the absence of fluids, volume diffusion of $\mathrm{Zr}$ in rutile is limited by grain boundary diffusion. In this regard, the lower $\mathrm{Zr}$ contents of rutile inclusions in garnet relative to those in zircon could be due to the effect of fluids, likely introduced in garnet through radial fractures (see Fig. 2c) (e.g., Meyer et al., 2011). In contrast, zircon is better than garnet in preventing fluid infiltration, so that rutile inclusions within zircon may preserve high $\mathrm{Zr}$ contents.

In addition, the high- $T\left(>900^{\circ} \mathrm{C}\right)$ decompression process during the initial stage of exhumation from UHP eclogite facies to granulite facies has led to significant partial melting of the eclogites in the region (Liu et al., 2011b; Gu, 2012). This partial melting on the zircons might have a marked effect, and only few zircons could survive and record the peak metamorphic temperatures (Liu et al., 2009).

In summary, rutile and zircon are robust enough to preserve compositions from earlier stages of a complex metamorphic history, and Zr-in-rutile and Ti-in-zircon thermometers have the potential to be very useful tools for estimating crystallization temperatures and peak metamorphic conditions. Furthermore, rutile included in a rigid phase such as zircon is able to retain its original $\mathrm{Zr}$ content. Therefore, for (ultra)high- $T$ metamorphic rocks, Zr-in-rutile, especially applied on rutile inclusions within zircon, may yield more reliable peak metamorphic temperatures than most other exchange geothermometers, which tend to partially re-equilibrate during cooling 
(Kooijman et al., 2012).

\subsection{Implications for peak metamorphic conditions and high-T exhumation}

Figure 10 shows the $P-T-t$ path of the NDZ eclogites as constrained by Ti-in-zircon and Zr-in-rutile thermometry (this study), conventional thermometry and SHRIMP U-Pb ages (Liu et al., 2011a; Gu, 2012). A variety of models for exhumation of UHP metamorphic rocks from mantle depths have been proposed (e.g., Ernst, 1971, 2001; Chemenda et al., 1995; Maruyama et al., 1996; Hacker et al., 2000; Liu et al., 2007b). The present and the already published data support a scenario in which the deeply subducted continental crust of the South China Block did not remain a single coherent unit, but formed several slices by multiple decoupling during subduction to mantle depths and subsequent exhumation; this decoupling may have been triggered by the difference in mechanic strength of rocks occurring at different levels of the continental crust (Liu et al., 2007b, 2011a; Liu and Li, 2008). Considering the weighted mean ages of UHP metamorphism (226 Ma) and HP eclogite-facies retrogression (214 Ma), the exhumation from mantle depths (ca. 4.0 GPa) to crustal depths of ca. 2.0 GPa must have been completed within about 12 Ma (Fig. 10). This implies that about $60 \mathrm{~km}$ of exhumation should have occurred within about $12 \mathrm{Ma}$, leading to an average exhumation rate of $0.5 \mathrm{~cm} / \mathrm{y}$. A comparatively lower exhumation rate of $\sim 0.4 \mathrm{~cm} / \mathrm{y}$ characterized the following evolution from HP eclogite-facies (214 Ma) to granulite-facies (207 Ma) conditions, corresponding to nearly isothermal exhumation at very high $T\left(>900^{\circ} \mathrm{C}\right)$ from pressures of 2.0 to $1.0 \mathrm{GPa}$. Therefore, the rapid exhumation rate of the initial stage of exhumation was followed by a comparatively slower exhumation at UHT conditions, which led to significant partial melting (Liu et al., 2011b; Gu, 2012). The protracted high-T evolution experienced by the NDZ eclogites may explain why UHP relicts are rarely preserved in the eclogites and in the associated rocks from the NDZ. In fact, although a relatively rapid exhumation is considered to be one of the factors favoring the preservation of UHP mineral assemblages (e.g., Mosenfelder et al., 2005; Liu et al., 2011b), a long residence time at high temperatures may have played an opposite role (Katayama and 
Maruyama, 2009).

UHT conditions may be reached in many different tectonic environments

(Santosh and Kusky, 2010) whereas the heat source to attain UHT conditions in the lower crust has been ascribed to asthenospheric mantle upwelling in response to delamination or thinning of the continental lithosphere (e.g., Harley, 2008). However, based on the present study, the high temperatures of $>900{ }^{\circ} \mathrm{C}$ estimated by Ti-in-zircon thermometer for the Neoproterozoic magmatism and granulite facies metamorphism in the NDZ could have been caused by a mantle plume, or an asthenospheric upwelling in response to large-scale continental rifting, resulting from the breakup of Rodinia at the Neoproterozoic in the South China Block (Ames et al., 1996; Rowley et al., 1997; Li et al., 2003; Liu et al., 2007a, 2010b). Recent works (e.g., Whittington et al., 2009; Santosh and Kusky, 2010) suggest that the lower crust has a low thermal diffusivity and is therefore able to retain heat for long time and that the underlying mantle has a higher mean temperature. Thus, in the case of extensional settings such as the continental rift zones, the heat and volatiles supplied by rising plumes might contribute to the generation of UHT metamorphism in the lower crust (Santosh and Kusky, 2010). In this context, the underplating and injection of the high-temperature melts may have triggered extensive crustal anatexis, producing large volumes of granitoids and associated basaltic rocks (precursors for most of UHP meta-igneous rocks in the Dabie-Sulu orogenic belt) along the periphery of the South 551 China Block, and local UHT metamorphism in the Neoproterozoic. Furthermore, petrological and geochronological studies have demonstrated that the eclogites 553 described in this study derived from Neoproterozoic mafic granulites (Liu et al. 2007a). In other words, the protolith of the eclogite was a mafic granulite that originated from underplating of mantle-derived magma onto the base of lower continental crust during the mid-Neoproterozoic (ca. $800 \mathrm{Ma}$ ) and was then subducted during the Triassic, experiencing UHP eclogite facies metamorphism at mantle depths. Therefore, this study provides additional thermometric evidence for the proposed Neoproterozoic mantle plume that led to the breakup of the supercontinent Rodinia, especially along the periphery of the South China Block. 


\section{Conclusions}

The temperatures estimated using zircons and rutile inclusions within zircon from the NDZ granulitized eclogites reveal a protracted high- $T\left(>900{ }^{\circ} \mathrm{C}\right)$ metamorphic history with at least three metamorphic stages, that occurred at significantly different pressures and ages, during Triassic continental subduction and subsequent exhumation. The investigated rutiles occur as inclusions in both garnet and zircon, and contain different $\mathrm{Zr}$ concentrations corresponding to different ranges of calculated temperatures. Rutile inclusions within zircons have the highest $\mathrm{Zr}$ concentrations, corresponding to $T>900{ }^{\circ} \mathrm{C}$. However, only $5-10 \%$ of the analyzed zircons record these high- $T$ conditions. Considering the significantly variable concentrations of $\mathrm{Zr}$ in rutile inclusions within garnet, the resulting broadly scattered calculated temperatures are probably related to retrograde re-equilibration and/or to local re-crystallization during retrogression. On the contrary, rutile inclusions within zircon are able to preserve primary compositions even at high- $T$ conditions $\left(>900{ }^{\circ} \mathrm{C}\right)$ yielding reliable temperatures for rutile crystallization and peak metamorphic conditions.

The present temperature estimates, combined with petrological observations and geochronological results, further suggest that the eclogite in the NDZ experienced a clockwise trajectory with a near-isothermal decompression path under high- $T$ conditions, multistage exhumation and rapid uplift during the early stages of exhumation. This protracted high- $T$ persistence with slow cooling may explain the rare preservation of UHP assemblages and compositions in the NDZ.

Finally, this study provides robust thermometric evidence in support of the previously proposed Neoproterozoic mantle plume that led to the breakup of the supercontinent Rodinia, especially along the northern periphery of the South China Block.

\section{Acknowledgments}

This study was supported by funds from the National Basic Research Program of 


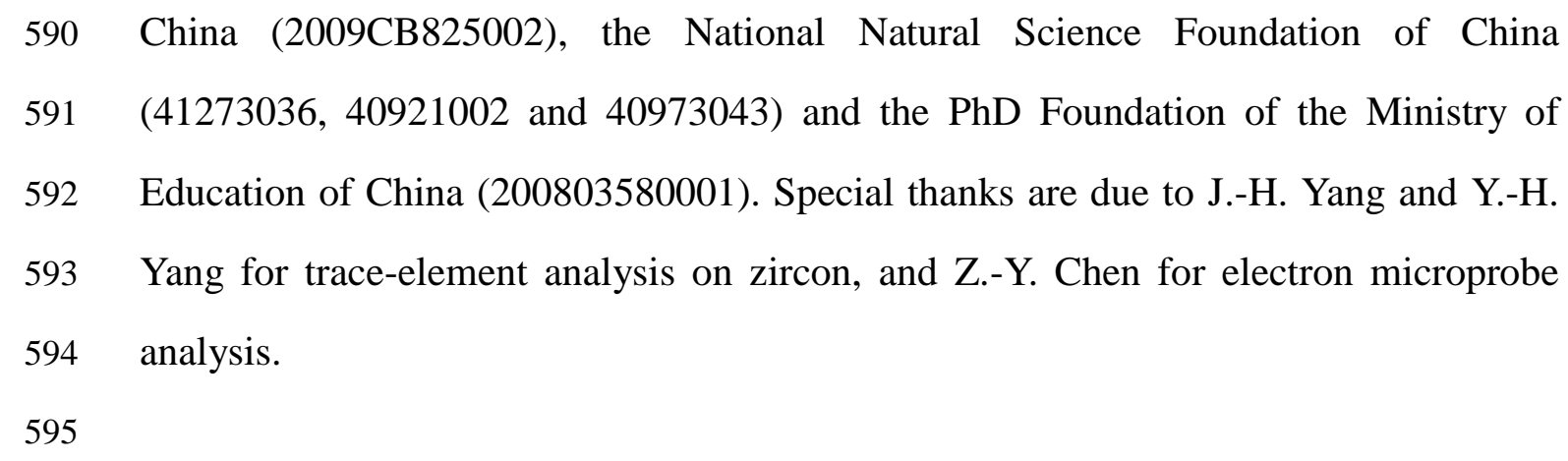




\section{References}

Ames, L., Zhou, G., Xiong, B., 1996. Geochronology and isotopic character of ultrahigh-pressure metamorphism with implications for collision of the Sino-Korean and Yangtze cratons, central China. Tectonics 15, 472-489.

Baldwin, J.A., Brown, M., Schmitz, M.D., 2007. First application of titanium-in-zircon thermometry to ultrahigh-temperature metamorphism. Geology 35, 295-298.

Baldwin, J.A., Brown, M., 2008. Age and duration of ultrahigh-temperature metamorphism in the Anápolis-Itaucu Complex, Southern Brasília Belt, central Brazil - constraints from U-Pb geochronology, mineral rare earth element chemistry and trace-element thermometry. Journal of Metamorphic Geology 26, 213-233.

Blundy, J.D., Holland, T.J.B., 1990. Calcic amphibole equilibria and a new amphibole-plagioclase geothermometer. Contributions to Mineralogy and Petrology 104, 208-224.

Boniface, N., Schenk, V., Appel, P., 2012. Paleoproterozoic eclogites of MORB-type chemistry and three Proterozoic orogenic cycles in the Ubendian Belt (Tanzania): Evidence from monazite and zircon geochronology, and geochemistry. Precambrian Research 192-195, 16-33.

Brown, M., 2007. Metamorphism, plate tectonics and the supercontinent cycle. Earth Science Frontiers 14, 1-18.

Bruno, M., Compagnoni, R., Rubbo, M., 2001. The ultra-high pressure coronitic and pseudomorphous reactions in a metagranodiorite from the Brossasco-Isasca Unit, Dora-Maira Massif, western Italian Alps: a petrographic study equilibrium thermodynamic modeling. Journal of Metamorphic Geology 19, 33-43.

Chemenda, A.I., Mattauer, M., Malavieille, J., Bokun, A.N., 1995. A mechanism for syn-collisional rock exhumation and associated normal faulting: results from physical modeling. Earth and Planetary Science Letters 132, 225-232.

Chen, N.S., Sun, M., You, Z.D., Malpas, J., 1998. Well-preserved garnet growth zoning in granulite from the Dabie Mountains, central China. Journal of 
Metamorphic Geology 16, 213-222.

Chen, Y., Ye, K., Liu, J.B., Sun, M., 2006. Multistage metamorphism of the Huangtuling granulite, Northern Dabie Orogen, eastern China: implications for the tectonometamorphic evolution of subducted lower continental crust. Journal of Metamorphic Geology 24, 633-654.

Chen, Z.Y., Li, Q.L., 2008. Zr-in-rutile thermometry in eclogite at Jinheqiao in the Dabie orogen and its geochemical implications. Chinese Science Bulletin 53, 768-776.

Cherniak, D.J., Manchester, J., Watson, E.B., 2007. Zr and Hf diffusion in rutile. Earth and Planetary Science Letters 262, 267-279.

Corfu, F., Hanchar, J.M., Hoskin, P.W.O., Kinny, P., 2003. Altas of zircon textures. Reviews in Mineralogy and Geochemistry 53, 469-500.

Dobrzhinetskaya, L.F., Green, H.W., Bozhilov, K.N., Mitchell, T.E., Dickerson, R.M., 2003. Crystallization environment of Kazakhstan microdiamond: evidence from nanometric inclusions and mineral associations. Journal of Metamorphic Geology 21, 425-437.

Ellis, D.J., Green, D.H., 1979. An experimental study of the effect of Ca upon garnet-clinopyroxene Fe-Mg exchange equilibration. Contributions to Mineralogy and Petrology 71, 13-22.

Ernst, W.G., 1971. Metamorphic zonations on presumably subducted lithospheric plates from Japan, California and the Alps. Contributions to Mineralogy and Petrology 34, 43-59.

Ernst, W.G., 2001. Subduction, ultrahigh-pressure metamorphism, and regurgitation of buoyant crustal slices-implications for arcs and continental growth. Physics of the Earth and Planetary Interiors 127, 253-275.

Ewing, T.A., Hermann, J., Rubatto, D., 2013. The robustness of the Zr-in-rutile and Ti-in-zircon thermometers during high-temperature metamorphism (Ivrea-Verbano Zone, northern Italy). Contributions to Mineralogy and Petrology 
165, 757-779.

Ferry, J.M., Watson, E.B., 2007. New thermodynamic models and revised calibrations for the Ti-in-zircon and Zr-in-rutile thermometers. Contributions to Mineralogy and Petrology 154, 429-437.

Fitzsimons, I.C.W., Harley, S.L., 1994. The influence of retrograde cation exchange on granulite $\mathrm{P}-\mathrm{T}$ estimates and a convergence technique for the recovery of peak metamorphic conditions. Journal of Petrology 35, 543-576.

Frost, B.R., Chacko, T., 1989. The granulite uncertainty principle: limitations on the thermometry in granulites. Journal of Geology 97, 435-450.

Fu, B., Page, F.Z., Cavosie, A.J., Clechenko, C.C., Fournelle, J., Kita, N.T., Lackey, J.S., Wilde, S.A., Valley, J.W., 2008. Ti-in-zircon thermometry: applications and limitations. Contributions to Mineralogy and Petrology 156, 197-215.

Gebauer, D., Schertl, H.P., Brix, M., Schreyer, W., 1997. 35 Ma old ultrahigh-pressure metamorphism and evidence for very rapid exhumation in the Dora Maira Massif, Western Alps. Lithos 41, 5-24.

Gu, X.F., 2012. Petrologic geochemistry and isotopic geochronology of the Luotian eclogites from the North Dabie complex zone, central China. PhD thesis. University of Science and Technology of China, 165 pp.

Hacker, B.R., Ratschbacher, L., Webb, L., McWilliams, M.O., Ireland, T., Calvert, A., Dong, S., Wenk, H.R., Chateigner, D., 2000. Exhumation of ultrahigh-pressure continental crust in east central China: Late Triassic-Early Jurassic tectonic unroofing. Journal of Geophysical Research 105, 13339-13364.

Harley, S.L., 2008. Refining the P-T records of UHT crustal metamorphism. Journal of Metamorphic Geology 26, 125-154.

Harley, SL., 2008. Refining the P-T records of UHT crustal metamorphism. Journal of Metamorphic Geology 26, 125-154.

Hemingway, B.S., Bohlen, S.R., Hankins, W.B., Westrum, E.J., Kuskov, O.L., 1998. Heat capacity and thermodynamic properties for coesite and jadeite: reexamination of the quartz-coesite equilibrium boundary. American Mineralogist 83, 409-418.

Hermann, J., Rubatto, D., Korsakov, A., Shatsky, V.S., 2001. Multiple zircon growth during fast exhumation of diamondiferous, deeply subducted continental crust 
686

687

688

689

690

691

692

693

694

695

696

697

698

699

700

701

702

703

704

705

706

707

708

709

710

711

712

713

714

715

(Kokchetav massif, Kazakhstan). Contributions to Mineralogy and Petrology 141, 66-82.

Hermann, J., Rubatto, D., 2003. Relating zircon and monazite domains to garnet growth zones: age and duration of granulite facies metamorphism in the Val Malenco lower crust. Journal of Metamorphic Geology 21, 833-852.

Jiao, S.J., Guo, J., Mao, Q., Zhao, R., 2011. Application of Zr-in-rutile thermometry: a case study from ultrahigh-temperature granulites of the Khondalite belt, North China Craton. Contributions to Mineralogy and Petrology 162, 379-393.

Katayama, I., Maruyama, S., 2009. Inclusion study in zircon from ultrahigh-pressure metamorphic rocks in the Kokchetav massif: an excellent tracer of metamorphic history. Journal of the Geological Society, London 166, 783-796.

Kelsey, D.E., 2008. On ultrahigh-temperature crustal metamorphism. Gondwana Research 13, 1-29.

Kennedy, C.S., Kennedy, G.C., 1976. The equilibrium boundary between graphite and diamond. Journal of Geophysical Research 81, 2467-2470.

Kooijman, E., Upadhyay, D., Mezger, K., Raith, M.M., Berndt, J., Srikantappa, C., 2011. Response of the $\mathrm{U}-\mathrm{Pb}$ chronometer and trace elements in zircon to ultrahigh-temperature metamorphism: The Kadavur anorthosite complex, southern India. Chemical Geology 290, 177-188.

Kooijman, E., Smit, M.A., Mezger, K., Berndt, J., 2012 Trace element systematics in granulite facies rutile: implications for $\mathrm{Zr}$ geothermometry and provenance studies. Journal of Metamorphic Geology 30, 397-412.

Krogh, E.J., 1988. The garnet-clinopyroxene Fe-Mg geothermometer - a reinterpretation of existing Experimental data. Contributions to Mineralogy and Petrology 99, 44-48.

Li, S., Xiao, Y., Liu, D., Ge, N., Zhang, Z., Sun, S.S., Cong, B., Zhang, R.Y., Hart, S.R., Wang, S., 1993. Collision of the North China and Yangtze blocks and formation of coesite-bearing eclogites: Timing and processes. Chemical Geology 109, 89-111.

Li, S., Jagoutz, E., Chen, Y., Li, Q., 2000. Sm-Nd and Rb-Sr isotope chronology of 
ultrahigh-pressure metamorphic rocks and their country rocks at Shuanghe in the Dabie Mountains, central China. Geochimica Cosmochimica Acta 64, 1077-1093.

Li, X.P., Zheng, Y.F., Wu, Y.B., Chen, F.K., Gong, B., Li, Y.L., 2004. Low-T eclogite in the Dabie terrane of China: petrological and isotopic constrains on fluid activity and radiometric dating. Contributions to Mineralogy and Petrology 148, $443-470$.

Li, Z.X., Li, X.H., Kinny, P.D., Wang, J., Zhang, S., Zhou, H., 2003. Geochronology of Neoproterozoic syn-rift magmatism in the Yangtze Craton, South China and correlations with other continents: evidence for a mantle superplume that broke up Rodinia. Precambrian Research 122, 85-109.

Liu, S.J., Li, J.H., Santosh, M., 2010a. First application of the revised Ti-in-zircon geothermometer to Paleoproterozoic ultrahigh-temperature granulites of Tuguiwula, Inner Mongolia, North China Craton. Contributions to Mineralogy and Petrology 159, 225-235.

Liu, Y.-C., Li, S., Xu, S., Li, H., Jiang, L., Chen, G., Wu, W., Su, W., 2000. U-Pb zircon ages of the eclogite and tonalitic gneiss from the northern Dabie Mountains, China and multi-overgrowths of metamorphic zircons. Geological Journal of China Universities 6, 17-423 (in Chinese with English abstract).

Liu, Y.-C., Xu, S., Li, S., Chen, G., Jiang, L., Zhou, C., Wu, W., 2001. Distribution and metamorphic $\mathrm{P}-\mathrm{T}$ condition of the eclogites from the mafic-ultramafic belt in the northern part of the Dabie Mountains. Acta Geologica Sinica 75, 385-395 (in Chinese with English abstract).

Liu, Y.-C., Li, S., Xu, S., Jahn, B.M., Zheng, Y.F., Zhang, Z., Jiang, L., Chen, G., Wu, W., 2005. Geochemistry and geochronology of eclogites from the northern Dabie Mountains, central China. Journal of Asian Earth Sciences 25, 431-443.

Liu, Y.-C., Li, S., Gu, X., Xu, S., Chen, G., 2007a. Ultrhigh-pressure eclogite transformed from mafic granulite in the Dabie orogen. Journal of Metamorphic Geology 25, 975-989.

Liu, Y.-C,, Li, S., Xu, S., 2007b. Zircon SHRIMP U-Pb dating for gneiss in northern 
Dabie high T/P metamorphic zone, central China: Implication for decoupling within subducted continental crust. Lithos 96, 170-185.

Liu, Y.-C., Li, S., 2008. Detachment within subducted continental crust and multi-slice successive exhumation of ultrahigh-pressure metamorphic rocks: Evidence from the Dabie-Sulu orogenic belt. Chinese Science Bulletin 53, 3105-3119.

Liu, Y.-C., Wang, A., Rolfo, F., Groppo, C., Gu, X., Song, B., 2009. Geochronological and petrological constraints on Palaeoproterozoic granulite facies metamorphism in southeastern margin of the North China Craton. Journal of Metamorphic Geology 27, 125-138.

Liu, Y.-C., Liu, L., Gu, X., Li, S., Liu, J., Song, B., 2010b. Occurrence of Neoproterozoic low-grade metagranite in the western Beihuaiyang zone, the Dabie orogen. Chinese Science Bulletin 55, 3490-3498.

Liu, Y.C., Gu, X., Li, S., Hou, Z.H., Song, B., 2011a. Multistage metamorphic events in granulitized eclogites from the North Dabie complex zone, central China: evidence from zircon $\mathrm{U}-\mathrm{Pb}$ age, trace element and mineral inclusion. Lithos 122, 107-121.

Liu, Y.-C., Gu, X., Rolfo, F., Chen, Z., 2011b. Ultrahigh-pressure metamorphism and multistage exhumation of eclogite from the Luotian dome, North Dabie Complex Zone (central China): Evidence from mineral inclusions and decompression texture. Journal of Asian Earth Sciences 42, 607-617.

Lucassen, F., Dulski, P., Abart, R., Franz, G., Rhede, D., Romer, R.L., 2010. Redistribution of HFSE during rutile replacement by titanite. Contributions to Mineralogy and Petrology 160, 279-295.

Luvizotto, G.L., Zack, T., 2009. Nb and Zr behavior in rutile during high-grade metamorphism and retrogression: an example from the Ivrea-Verbano Zone. Chemical Geology 261, 303-317.

Malaspina, N., Hermann, J., Scambelluri, M., Compagnoni, R., 2006. Multistage metasomatism in ultrahigh-pressure mafic rocks from the North Dabie Complex (China). Lithos 90, 19-42. 
Maruyama, S., Liou, J.G., Terabayashi, M., 1996. Blueschists and eclogites of the world, and their exhumation. International Geology Review 38, 485-594.

Meyer, M., John, T., Brandt, S., Klemd, R., 2011. Trace element composition of rutile and the application of Zr-in-rutile thermometry to UHT metamorphism (Epupa Complex, NW Namibia). Lithos 126, 388-401.

Miller, C., Zanetti, A., Thöni, M., 2007. Eclogitisation of gabbroic rocks: redistribution of trace elements and $\mathrm{Zr}$ in rutile thermometry in an Eo-Alpine subduction zone (Eastern Alps). Chemical Geology 239, 96-123.

Möller, A., O’Brien, P.J., Kennedy, A., Kröner, A., 2002. Polyphase zircon in ultrahigh-temperature granulites (Rogaland, SW Norway): constraints for $\mathrm{Pb}$ diffusion in zircon. Journal of Metamorphic Geology 20, 727-740.

Moraes, R., Brown, M., Fuck, R.A., Camargo, M.A., Lima, T.M., 2002. Characterization and P-T evolution of melt-bearing ultrahigh-temperature granulites: an Example from the Anápolis-Itauçu Complex of the Brasília Fold Belt, Brazil. Journal of Petrology 43, 1673-1705.

Morimoto, N., Ferguson, A.K., Ginzburg, I.V., Ross, M., Seifert, F.A., Seifert, J., Seifert, Z., Aoki, K., Gottardi, G., 1988. Nomenclature of pyroxenes. American Mineralogist 73, 1123-1133.

Mosenfelder, J.L., Schertl, H.P., Smyth, J.R., Liou, J.G., 2005. Factors in the preservation of coesite: The importance of fluid infiltration. American Mineralogist 90, 779-789.

Okay, A.I., Xu, S., Sengör, A.M.C., 1989. Coesite from the Dabie Shan eclogites, central China. European Journal of Mineralogy 1, 595-598.

Okay, A.I., 1993. Petrology of a diamond and coesite-bearing metamorphic terrain: Dabie Shan, China. European Journal of Mineralogy 5, 659-675.

Okay, A.I., Sengör, A.M.C., Satir, M., 1993. Tectonics of an ultrahigh-pressure metamorphic terrane: the Dabie Shan/Tongbai orogen, China. Tectonics 12, $1320-1334$.

Page, F.Z., Fu, B., Kita, N.T., Fournelle, J., Spicuzza, M.J., Schulze, D.J., Viljoen, F., Basei, M.A.S., Valley, J.W., 2007. Zircons from kimberlite: new insights from 

Cosmochimica Acta 71, 3887-3903.

Raheim, A., Green, D.H., 1974. Experimental determination of the temperature and pressure dependence of the Fe-Mg partition coefficient for coexisting garnet and clinopyroxene. Contributions to Mineralogy and Petrology 48, 179-203.

Raith, M., Karmakar, S., Brown, M., 1997. Ultra-high-temperature metamorphism and multi-stage decompressional evolution of sapphirine granulites from the Palni hill ranges, southern India. Journal of Metamorphic Geology 15, 379-399.

Rolfo, F., Compagnoni, R., Wu, W., Xu, S., 2004. A coherent lithostratigraphic unit in the coesite-eclogite complex of Dabie Shan, China: geologic and petrologic evidence. Lithos 73, 71-94.

Rowley, D.B., Xue, F., Tucker, R.D., Peng, Z.X., Baker, J., Davis, A., 1997. Ages of ultrahigh pressure metamorphism and protolith orthogneisses from the eastern Dabie Shan: U/Pb zircon geochronology. Earth and Planetary Science Letters 151, 191-203.

Rubatto, D., Gebauer, D., Compagnoni, R., 1999. Dating of eclogite-facies zircons: the age of Alpine metamorphism in the Sesia-Lanzo zone (western Alps). Earth and Planetary Science Letters 167, 141-158.

Santosh, M., Kusky, T., 2010. Origin of paired high pressure-ultrahigh-temperature orogens: a ridge subduction and slab window model. Terra Nova 22, 35-42.

Spear, F.S., Wark, D.A., Cheney, J.T., Schumacher, J.C., Watson, E.B., 2006. Zr-in-rutile thermometry in blueschists from Sifnos, Greece. Contributions to Mineralogy and Petrology 152, 375-385.

Timms, N.E., Kinny, P.D., Reddy, S.M., Evans, K., Clark, C., Healy, D., 2011. Relationship among titanium, rare earth elements, $\mathrm{U}-\mathrm{Pb}$ ages and deformation microstructures in zircon: Implications for Ti-in-zircon thermometry. Chemical Geology 280, 33-46.

Tomkins, H.S., Powell, R., Ellis, D.J., 2007. The pressure dependence of the zirconium-in-rutile thermometer. Journal of Metamorphic Geology 25, 703-713.

835 Triebold S, von Eynatten H, Luvizotto G L, Zack T (2007) Deducing source rock 

Germany. Chemical Geology 244, 421-436.

Triebold, S., Luvizotto, G.L., Tolosana-Delgado, R., Zack, T., von Eynatten, H., 2011.

Discrimination of $\mathrm{TiO}_{2}$ polymorphs in sedimentary and metamorphic rocks. Contributions to Mineralogy and Petrology 161, 581-596.

Wang, S., Li, S., An, S., Hou, Z., 2012. A granulite record of multistage metamorphism and REE behavior in the Dabie orogen: Constraints from zircon and rock-forming minerals. Lithos 136-139, 109-125.

Wang, X., Liou, J.G., Mao, H.K., 1989. Coesite -bearing eclogites from the Dabie Mountains in central China. Geology 17, 1085-1088.

Watson, E.B., Harrison, T.M., 2005. Zircon thermometer reveals minimum melting conditions on earliest earth. Science 308, 841-844.

Watson, E.B., Wark, D.A., Thomas, J.B., 2006. Crystallization thermometers for zircon and rutile. Contributions to Mineralogy and Petrology 151, 413-433.

Wells, R.A., 1977. Pyroxene thermometry in simple and complex systems. Contributions to Mineralogy and Petrology 62, 129-139.

Whitehouse, M.J., Platt, J.P., 2003. Dating high-grade metamorphism—constraints from rare-earth elements in zircons and garnet. Contributions to Mineralogy and Petrology 145, 61-74.

Whittington, A.G., Hofmeister, A.M., Nabelek, P.I., 2009. Temperature dependent thermal diffusivity of the Earth's crust and implications for magmatism. Nature 458, 319-321.

Williams, I.S., Buick, I.S., Cartwright, I., 1996. An extended episode of early Mesoproterozoic metamorphic fluid flow inthe Reynolds Range, central Australia. Journal of Metamorphic Geology 14, 29-47.

Whitney, D.L., Evans, B.W., 2010. Abbreviations for names of rock-forming minerals. American Mineralogist 95, 185-187.

Wood, B.J., Banno, S., 1973. Garnet-orthopyroxene and orthopyroxene-clinopyroxene relationship in simple and complex systems. Contributions to Mineralogy and 
Petrology 42, 109-124.

Wood, B.J., 1974. The solubility of alumina in orthopyroxene coexisting with garnet. Contributions to Mineralogy and Petrology 46, 1-15.

Wu, Y.B., Zheng, Y., Gao, S., Jiao, W., Liu, Y., 2008. Zircon U-Pb age and trace element evidence for Paleoproterozoic granulite-facies metamorphism and Archean crustal rocks in the Dabie Orogen. Lithos 101, 308-322.

Xiao, Y., Hoefs, J., van den Kerkhof, A.M., Li, S., 2001. Geochemical constraints of the eclogite and granulite facies metamorphism as recognized in the Raobazhai complex from North Dabie Shan, China. Journal of Metamorphic Geology 19, 3-19.

Xie, Z., Chen, J., Cui, Y., 2010. Episodic growth of zircon in UHP orthogneisses from the North Dabie Terrane of east-central China: implications for crustal architecture of a collisional orogen. Journal of Metamorphic Geology 28, 979-995.

Xu, S., Okay, A.I., Ji, S., Sengör, A.M.C., Su, W., Liu, Y.-C., Jiang, L., 1992. Diamond from the Dabie Shan metamorphic rocks and its implication for tectonic setting. Science 256, 80-82.

Xu, S., Liu, Y.-C., Su, W., Wang, R., Jiang, L., Wu, W., 2000. Discovery of the eclogite and its petrography in the Northern Dabie Mountain. Chinese Science Bulletin 45, 273-278.

Xu, S., Liu, Y.-C., Chen, G., Compagnoni, R., Rolfo, F., He, M., Liu, H., 2003. New finding of micro-diamonds in eclogites from Dabie-Sulu region in central-eastern China. Chinese Science Bulletin 48, 988-994.

Xu, S., Liu, Y.-C., Chen, G., Ji, S., Ni, P., Xiao, W., 2005. Microdiamonds, their classification and tectonic implications for the host eclogites from the Dabie and Su-Lu regions in central eastern China. Mineralogical Magazine 69, 509-520.

Yuan, H.L., Gao, S., Liu, X.M., Li, H.M., Gunther, D., Wu, F.Y., 2004. Accurate U-Pb age and trace element determinations of zircon by laser ablation-inductively coupled plasma mass spectrometry. Geostandards and Geoanalytical Research 28, $353-370$.

Zack, T., Moraes, R., Kronz, A., 2004. Temperature dependence of Zr in rutile: 


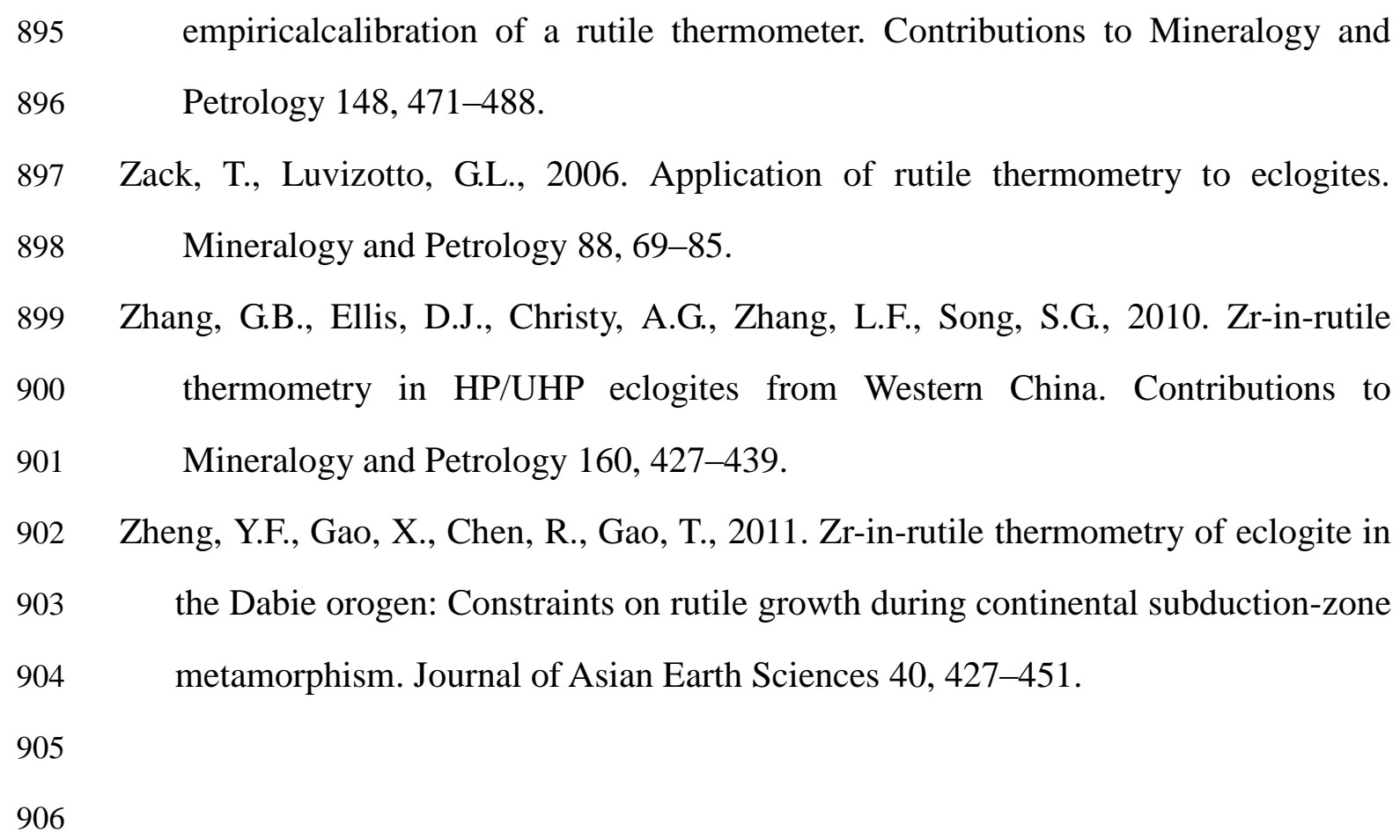




\section{Figure captions}

Figure 1 Schematic geological map of the Dabie orogen, with inset showing its location within the Triassic Qinling—Dabie-Sulu collision orogen in central China. Sample localities with sample numbers are described in detail in the text. BZ, Beihuaiyang zone; NDZ, North Dabie complex zone; CDZ, Central Dabie UHP metamorphic zone; SDZ, South Dabie low- $T$ eclogite zone; SZ, Susong complex zone; HMZ, Huwan mélange zone; HZ, Hong'an low- $T$ eclogite zone; DC, amphibolite-facies Dabie complex; XMF, Xiaotian-Mozitan fault; WSF, Wuhe-Shuihou fault; HMF, Hualiangting-Mituo fault; TSF, Taihu-Shanlong fault; TLF, Tan-Lu fault; SMF, Shangcheng-Macheng fault.

Figure 2 Photomicrographs of eclogite (sample 07LT6-1) from the Luotian dome in the Dabie orogen. a. Omphacite (Omp) and quartz (Qtz) inclusions in garnet with two generations of symplectites $(\mathrm{Hy}+\mathrm{Di}+\mathrm{Pl}$ and $\mathrm{Hbl}+\mathrm{Pl}+\mathrm{Mt})$; b. Omphacite, rutile and quartz inclusions in garnet, rimmed by distinctive double symplectites (Liu et al. 2011b); c. Quartz and rutile inclusions in garnet with well-developed radial cracks (Liu et al. 2011b); d. Clinopyroxene (Cpx) + plagioclase (Pl) + quartz (Qtz) intergrowth after omphacite in garnet. Mineral abbreviations are after Whitney and Evans (2010).

Figure 3 Cathodoluminescence (CL) (a, c, e, g and i-k) and Back scattered electron (BSE) images (b, d, f, h and l) for zircon from sample 07LT6-1. Zircon (a) and (b), (c) and (d), (e) and (f), (g) and (h), and (k) and (l) are the same grains, respectively. The open circles are analysis spots with available ${ }^{206} \mathrm{~Pb} /{ }^{238} \mathrm{U}$ ages. Omp represents low-Na omphacite as mentioned in the text.

Figure 4 WEF-Jd-Ae diagram (after Morimoto et al. 1988) of clinopyroxenes occurring as inclusions in garnet and zircon of the eclogite (sample 07LT6-1) from the Luotian dome. 
Figure 5 Representative Raman spectra of mineral inclusions in zircon of eclogites from the Luotian dome. (a) Omphacite and quartz; (b) Rutile; (c) Garnet. These spectra also contain host zircon peaks at 227-228, 357-359, 440-441, 975-976 and 1009-1010 cm ${ }^{-1}$.

Figure 6 Calculated $\mathrm{Zr}$ temperatures $\left({ }^{\circ} \mathrm{C}\right)$ of rutile occurring as inclusions in garnet (a), in zircon inner mantle (b), in zircon outer mantle (c) and in zircon rim (d) from the investigated samples in the North Dabie complex zone.

Figure 7 Diagram of $\mathrm{Zr}$-in-rutile temperatures $\left({ }^{\circ} \mathrm{C}\right)$ estimated at the inferred metamorphic pressures (GPa) for the eclogites from the Luotian dome. Red circles, black circles and black triangles represent calculated temperatures from inner mantle (M1), outer mantle (M2) and rim domains of zircon, respectively (see explanation in the text).

Figure 8 Diagram of zircon $\mathrm{U}-\mathrm{Pb}$ age $(\mathrm{Ma})$ and corresponding Ti-in-zircon temperatures $\left({ }^{\circ} \mathrm{C}\right)$ for the Type 1 eclogites from the Luotian dome. Square, circle and triangle symbols represent calculated temperatures from samples 03LT1-1, 06LT3-2 and 07LT6-1, respectively. Blue, red, purple, green and gray symbols denote different groups of metamorphic zircon domains formed at 230-240 Ma (pre-peak mantle), 220-230 Ma (UHP eclogite-facies inner mantle M1), 210-220 Ma (HP eclogite-facies outer mantle M2), 200-210 Ma (granulite-facies rim) and 180-200 Ma (amphibolites-facies rim), respectively (see explanation in the text).

Figure 9 Diagram of zircon U-Pb age (Ma) and corresponding Ti-in-zircon temperatures $\left({ }^{\circ} \mathrm{C}\right)$ for the Type 2 eclogites (samples LT9 and LT10) from the Luotian dome. Black square and red circle symbols refer to the Neoproterozoic magmatic and metamorphic zircon cores dated by Liu et al. (2007a). 
966 Figure 10 A schematic $P-T-t$ path for the eclogites from the Luotian dome in the 967 Dabie orogen. The equilibrium lines for diamond = graphite (Kennedy and Kennedy, 968 1976) and coesite $=$ quartz (Hemingway et al., 1998) are shown. 
Table 1 Electron microprobe analyses of representative minerals from the eclogite (sample 07LT6-1) in the Luotian dome (wt\%)

\begin{tabular}{|c|c|c|c|c|c|c|c|c|c|c|}
\hline \multirow{3}{*}{$\begin{array}{c}\text { Mineral } \\
\text { No. } \\
\text { Site }\end{array}$} & \multicolumn{2}{|c|}{ Garnet } & \multicolumn{4}{|c|}{ High-Na omphacite } & \multicolumn{4}{|c|}{ Low-Na omphacite } \\
\hline & Gt1 & Gt1a & Omp4 & Omp1 & Omp2 & Omp3 & Cpx1 & Cpx4 & Cpx5 & Cpx2 \\
\hline & $\mathrm{m}$ & iz & ig & ig & ig & ig & iz & iz & iz & iz \\
\hline $\mathrm{SiO}_{2}$ & 38.01 & 39.44 & 55.58 & 55.49 & 54.34 & 54.41 & 55.20 & 54.93 & 53.35 & 56.77 \\
\hline $\mathrm{TiO}_{2}$ & 0.10 & 0.03 & 0.03 & 0.06 & 0.05 & 0.10 & 0.04 & 0.04 & 0.00 & 0.00 \\
\hline $\mathrm{Al}_{2} \mathrm{O}_{3}$ & 21.02 & 22.00 & 10.07 & 10.48 & 10.71 & 10.26 & 7.64 & 6.18 & 8.90 & 8.36 \\
\hline $\mathrm{FeO}$ & 26.89 & 23.50 & 7.04 & 6.71 & 7.35 & 7.12 & 5.74 & 6.53 & 5.47 & 5.74 \\
\hline $\mathrm{Cr}_{2} \mathrm{O}_{3}$ & 0.19 & 0.00 & 0.00 & 0.04 & 0.10 & 0.00 & 0.02 & 0.05 & 0.03 & 0.00 \\
\hline MnO & 0.24 & 0.82 & 0.01 & 0.03 & 0.08 & 0.06 & 0.15 & 0.05 & 0.03 & 0.14 \\
\hline MgO & 3.82 & 6.52 & 7.93 & 7.84 & 7.44 & 8.05 & 10.43 & 11.40 & 10.15 & 10.63 \\
\hline $\mathrm{CaO}$ & 9.88 & 8.12 & 12.71 & 12.88 & 13.14 & 13.76 & 17.30 & 17.81 & 19.14 & 15.05 \\
\hline $\mathrm{Na}_{2} \mathrm{O}$ & 0.06 & 0.00 & 6.62 & 6.33 & 6.44 & 6.09 & 3.43 & 2.98 & 2.41 & 3.89 \\
\hline $\mathbf{K}_{2} \mathrm{O}$ & 0.00 & 0.00 & 0.00 & 0.02 & 0.00 & 0.00 & 0.00 & 0.00 & 0.00 & 0.00 \\
\hline Total & 100.02 & 100.43 & 99.99 & 99.88 & 99.65 & 99.85 & 99.95 & 99.97 & 99.48 & 100.62 \\
\hline O & 12 & 12 & 6 & 6 & 6 & 6 & 6 & 6 & 6 & 6 \\
\hline $\mathbf{S i}$ & 2.979 & 3.030 & 1.992 & 1.994 & 1.959 & 1.959 & 2.009 & 2.004 & 1.962 & 2.044 \\
\hline $\mathbf{A l}^{\mathrm{IV}}$ & 0.021 & 0.000 & 0.008 & 0.006 & 0.041 & 0.041 & 0.000 & 0.000 & 0.038 & 0.000 \\
\hline $\mathrm{Al}^{\mathrm{VI}}$ & 1.919 & 1.990 & 0.416 & 0.437 & 0.414 & 0.393 & 0.327 & 0.266 & 0.347 & 0.335 \\
\hline $\mathrm{Fe}^{3+}$ & 0.088 & 0.075 & 0.049 & 0.005 & 0.070 & 0.066 & 0.000 & 0.000 & 0.000 & 0.000 \\
\hline $\mathbf{T i}$ & 0.006 & 0.002 & 0.001 & 0.002 & 0.001 & 0.003 & 0.001 & 0.001 & 0.000 & 0.000 \\
\hline $\mathrm{Fe}^{2+}$ & 1.674 & 1.434 & 0.162 & 0.196 & 0.152 & 0.147 & 0.175 & 0.199 & 0.168 & 0.099 \\
\hline $\mathrm{Cr}$ & 0.012 & 0.000 & 0.000 & 0.001 & 0.003 & 0.000 & 0.001 & 0.001 & 0.001 & 0.000 \\
\hline Mg & 0.446 & 0.747 & 0.424 & 0.420 & 0.400 & 0.432 & 0.566 & 0.620 & 0.556 & 0.571 \\
\hline Mn & 0.016 & 0.053 & 0.000 & 0.001 & 0.002 & 0.002 & 0.005 & 0.002 & 0.001 & 0.004 \\
\hline $\mathrm{Ca}$ & 0.830 & 0.668 & 0.488 & 0.496 & 0.508 & 0.531 & 0.675 & 0.696 & 0.754 & 0.581 \\
\hline $\mathrm{Na}$ & 0.009 & 0.000 & 0.460 & 0.441 & 0.450 & 0.425 & 0.242 & 0.211 & 0.172 & 0.272 \\
\hline $\mathbf{K}$ & 0.000 & 0.000 & 0.000 & 0.001 & 0.000 & 0.000 & 0.000 & 0.000 & 0.000 & 0.000 \\
\hline
\end{tabular}

Note: m, matrix; ig, inclusion in garnet; iz, inclusion in zircon. Garnet/omphacite stoichiometries and the amount of $\mathrm{Fe}^{3+}$ and $\mathrm{Fe}^{2+}$ were estimated on the base of eight/four cations and the charge-balance constraint. 
Table 2 Major element compositions and $\mathrm{Zr}$ temperatures of rutile inclusions in zircon and zircon U-Pb ages for eclogites from the Luotian dome in the North Dabie complex zone

\begin{tabular}{|c|c|c|c|c|c|c|c|c|c|c|c|c|}
\hline Analysis No. & Locality & $\mathrm{SiO}_{2}$ & $\mathrm{Al}_{2} \mathrm{O}_{3}$ & $\mathrm{TiO}_{2}$ & $\mathrm{FeO}$ & $\mathrm{Cr}_{2} \mathrm{O}_{3}$ & $\mathrm{Nb}_{2} \mathrm{O}_{5}$ & $\mathrm{ZrO}_{2}$ & Total & $\operatorname{Zr}(\mathrm{ppm})$ & $\mathrm{T}\left({ }^{\circ} \mathrm{C}\right)$ & $\begin{array}{c}{ }^{206} \mathrm{~Pb} /{ }^{238} \mathrm{U} \\
\text { Age(Ma) }\end{array}$ \\
\hline \multicolumn{13}{|l|}{$03 L T 1-1$} \\
\hline 03LT1-1Rt1 & M2 & 0.00 & 0.00 & 96.65 & 0.36 & 0.04 & 0.06 & 0.19 & 97.29 & 1421 & 844 & $214 \pm 3$ \\
\hline 03LT1-1Rt1a & M2 & 0.00 & 0.00 & 97.21 & 0.35 & 0.04 & 0.03 & 0.16 & 97.79 & 1199 & 825 & $214 \pm 3$ \\
\hline 03LT1-1Rt4 & M1 & 0.00 & 0.00 & 97.41 & 0.49 & 0.04 & 0.05 & 0.33 & 98.31 & 2419 & 988 & \\
\hline 03LT1-1Rt4a & M2 & 0.00 & 0.00 & 97.98 & 0.52 & 0.04 & 0.06 & 0.35 & 98.94 & 2560 & 915 & \\
\hline 03LT1-1Rt4b & M2 & 0.00 & 0.00 & 98.27 & 0.47 & 0.03 & 0.07 & 0.34 & 99.19 & 2538 & 913 & \\
\hline 03LT1-1Rt5 & M2 & 0.00 & 0.00 & 98.00 & 0.25 & 0.03 & 0.08 & 0.31 & 98.68 & 2301 & 901 & \\
\hline 03LT1-1Rt1 & M2 & 0.00 & 0.00 & 98.33 & 0.33 & 0.04 & 0.07 & 0.11 & 98.89 & 843 & 788 & \\
\hline 03LT1-1Rt6 & M2 & 0.00 & 0.00 & 97.56 & 0.54 & 0.04 & 0.08 & 0.73 & 98.95 & 5416 & 1018 & \\
\hline 03LT1-1Rt9 & M2 & 0.00 & 0.00 & 98.51 & 0.47 & 0.03 & 0.08 & 0.14 & 99.23 & 1014 & 807 & \\
\hline 03LT1-1Rt6a & M2 & 0.00 & 0.00 & 97.68 & 0.56 & 0.03 & 0.05 & 0.22 & 98.53 & 1591 & 857 & \\
\hline 03LT1-1Rt9 & M2 & 0.00 & 0.00 & 96.61 & 2.60 & 0.03 & 0.05 & 0.11 & 99.40 & 814 & 785 & \\
\hline 03LT1-1Rt2 & M1 & 0.07 & 0.00 & 98.39 & 0.45 & 0.08 & 0.09 & 0.34 & 99.43 & 2515 & 993 & \\
\hline 03LT1-1Rt3 & M1 & 0.04 & 0.00 & 99.35 & 0.36 & 0.07 & 0.06 & 0.22 & 100.1 & 1628 & 936 & \\
\hline 03LT1-1Rt7 & M2 & 0.04 & 0.00 & 98.11 & 0.53 & 0.07 & 0.06 & 0.15 & 98.96 & 1110 & 817 & \\
\hline 03LT1-1Rt8 & M2 & 0.05 & 0.00 & 98.77 & 0.53 & 0.07 & 0.07 & 0.37 & 99.86 & 2737 & 923 & \\
\hline 03LT1-1Rt7 & M2 & 0.05 & 0.00 & 98.36 & 0.26 & 0.06 & 0.07 & 0.30 & 99.10 & 2220 & 897 & \\
\hline 03LT1-1Rt1b & M2 & 0.05 & 0.00 & 98.38 & 0.44 & 0.04 & 0.09 & 0.15 & 99.16 & 1131 & 819 & \\
\hline 03LT1-1ARt2 & M1 & 0.04 & 0.00 & 97.98 & 0.37 & 0.02 & 0.07 & 0.23 & 98.72 & 1702 & 941 & \\
\hline 03LT1-1ARt3 & M1 & 0.05 & 0.00 & 97.53 & 0.48 & 0.04 & 0.07 & 0.38 & 98.55 & 2800 & 1008 & \\
\hline $\begin{array}{c}\text { 03LT1-1ARt1 } \\
\text { 06LT3-2 }\end{array}$ & \multicolumn{12}{|c|}{$06 L T 3-2$} \\
\hline 06LT3-2Rt2 & M2 & 0.00 & 0.00 & 98.19 & 0.14 & 0.03 & 0.01 & 0.15 & 98.51 & 1080 & 814 & \\
\hline 06LT3-2Rt3 & M1 & 0.00 & 0.00 & 97.46 & 0.39 & 0.02 & 0.01 & 0.25 & 98.13 & 1864 & 954 & \\
\hline 06LT3-2Rt4 & M2 & 0.00 & 0.00 & 97.40 & 0.22 & 0.02 & 0.02 & 0.78 & 98.43 & 5771 & 1028 & \\
\hline 06LT3-2Rt5 & rim & 0.04 & 0.00 & 98.41 & 0.21 & 0.02 & 0.00 & 0.28 & 98.97 & 2098 & 838 & $200 \pm 18$ \\
\hline 06LT3-2Rt5a & rim & 0.04 & 0.00 & 98.09 & 0.20 & 0.05 & 0.01 & 0.32 & 98.72 & 2368 & 852 & $200 \pm 18$ \\
\hline 06LT3-2Rt1 & M2 & 0.05 & 0.00 & 97.92 & 0.15 & 0.06 & 0.01 & 0.18 & 98.37 & 1332 & 837 & \\
\hline 06LT3-2Rt2a & M2 & 0.03 & 0.00 & 97.89 & 0.15 & 0.02 & 0.01 & 0.16 & 98.27 & 1202 & 826 & \\
\hline \multicolumn{13}{|l|}{ 07LT6-1 } \\
\hline 07LT6-1Rt1 & M1 & 0.03 & 0.00 & 98.69 & 0.48 & 0.02 & 0.04 & 0.14 & 99.41 & 1033 & 881 & $221 \pm 6$ \\
\hline 07LT6-1Rt2 & M1 & 0.04 & 0.00 & 98.22 & 0.63 & 0.01 & 0.03 & 0.24 & 99.17 & 1790 & 948 & $228 \pm 5$ \\
\hline 07LT6-1Rt3 & M1 & 0.05 & 0.00 & 98.13 & 0.48 & 0.05 & 0.03 & 0.33 & 99.06 & 2405 & 987 & \\
\hline 07LT6-1Rt4 & M1 & 0.04 & 0.00 & 98.57 & 0.40 & 0.03 & 0.04 & 0.26 & 99.34 & 1955 & 959 & \\
\hline 07LT6-1Rt5 & M2 & 0.06 & 0.00 & 98.34 & 0.52 & 0.02 & 0.04 & 0.27 & 99.25 & 1978 & 883 & \\
\hline
\end{tabular}




\begin{tabular}{|c|c|c|c|c|c|c|c|c|c|c|c|c|}
\hline 07LT6-1Rt6 & M2 & 0.06 & 0.00 & 98.07 & 0.47 & 0.02 & 0.04 & 0.40 & 99.06 & 2983 & 934 & \\
\hline 07LT6-1Rt7 & M2 & 0.06 & 0.00 & 98.50 & 0.49 & 0.03 & 0.04 & 0.20 & 99.32 & 1458 & 847 & \\
\hline 07LT6-1Rt8 & M2 & 0.03 & 0.00 & 98.68 & 0.55 & 0.02 & 0.00 & 0.22 & 99.51 & 1627 & 860 & \\
\hline 07LT6-1Rt9 & M2 & 0.07 & 0.00 & 98.67 & 0.52 & 0.03 & 0.16 & 0.29 & 99.75 & 2163 & 894 & \\
\hline 07LT6-1Rt10 & M2 & 0.06 & 0.00 & 98.56 & 0.45 & 0.03 & 0.04 & 0.17 & 99.32 & 1286 & 833 & \\
\hline 07LT6-1Rt11 & M2 & 0.06 & 0.00 & 98.57 & 0.50 & 0.03 & 0.04 & 0.25 & 99.44 & 1876 & 876 & \\
\hline 07LT6-1Rt12 & M1 & 0.05 & 0.00 & 98.33 & 0.46 & 0.03 & 0.04 & 0.25 & 99.16 & 1819 & 950 & \\
\hline 07LT6-1Rt13 & M2 & 0.04 & 0.00 & 98.59 & 0.36 & 0.02 & 0.01 & 0.29 & 99.30 & 2133 & 892 & \\
\hline 07LT6-1Rt14 & M2 & 0.06 & 0.00 & 98.57 & 0.41 & 0.02 & 0.03 & 0.21 & 99.30 & 1520 & 852 & \\
\hline 07LT6-1Rt15 & M1 & 0.07 & 0.00 & 98.18 & 0.46 & 0.02 & 0.00 & 0.26 & 98.99 & 1929 & 957 & $226 \pm 7$ \\
\hline 07LT6-1Rt16 & M1 & 0.06 & 0.00 & 98.17 & 0.46 & 0.02 & 0.00 & 0.34 & 99.05 & 2495 & 992 & $228 \pm 7$ \\
\hline 07LT6-1Rt17 & M2 & 0.08 & 0.00 & 97.76 & 0.44 & 0.04 & 0.05 & 0.45 & 98.82 & 3297 & 948 & \\
\hline 07LT6-1Rt18 & M2 & 0.07 & 0.00 & 98.61 & 0.11 & 0.01 & 0.02 & 0.25 & 99.08 & 1831 & 873 & \\
\hline 07LT6-1Rt19 & M2 & 0.05 & 0.00 & 97.65 & 0.46 & 0.03 & 0.04 & 0.40 & 98.63 & 2977 & 934 & \\
\hline 07LT6-1Rt20 & M2 & 0.07 & 0.00 & 98.61 & 0.28 & 0.03 & 0.00 & 0.20 & 99.18 & 1447 & 846 & \\
\hline $\begin{array}{c}\text { 07LT6-1Rt1a } \\
\text { 09LT1 }\end{array}$ & M1 & 0.03 & 0.00 & 98.46 & 0.48 & 0.02 & 0.00 & 0.15 & 99.14 & 1078 & 886 & $221 \pm 6$ \\
\hline 09LT1Rt1 & M1 & 0.03 & 0.00 & 98.43 & 0.41 & 0.03 & 0.00 & 0.33 & 99.24 & 2405 & 987 & \\
\hline $\begin{array}{c}\text { 09LT1Rt2 } \\
\text { 09LT2 }\end{array}$ & M1 & 0.21 & 0.00 & 98.15 & 0.32 & 0.02 & 0.03 & 0.58 & 99.32 & 4310 & 1072 & \\
\hline 09LT2Rt2 & M2 & 0.05 & 0.00 & 97.88 & 0.39 & 0.05 & 0.01 & 0.28 & 98.66 & 2072 & 888 & \\
\hline 09LT2Rt1 & M1 & 0.14 & 0.00 & 97.45 & 0.58 & 0.05 & 0.00 & 0.51 & 98.73 & 3773 & 1052 & $224 \pm 3$ \\
\hline
\end{tabular}

Notes: M1, inner mantle; M2, outer mantle. All rutiles in this table are inclusions in zircon, the analysis method was EPMA. Temperatures were calculated by Tomkins et al. (2007); the pressures were set to be 4 GPa for M1, 2 GPa for M2 and 1 GPa for rim domains. Age data from Liu et al. (2011a) and Gu (2012). 
Table 3 Major element compositions and $\mathrm{Zr}$ temperatures of rutile inclusions in garnet for eclogites from the Luotian dome in the North Dabie complex zone

\begin{tabular}{|c|c|c|c|c|c|c|c|c|c|c|c|}
\hline Analysis No. & $\mathrm{SiO}_{2}$ & $\mathrm{Al}_{2} \mathrm{O}_{3}$ & $\mathrm{FeO}$ & $\mathrm{TiO}_{2}$ & $\mathrm{Cr}_{2} \mathrm{O}_{3}$ & $\mathrm{Nb}_{2} \mathrm{O}_{5}$ & $\mathrm{ZrO}_{2}$ & Total & $\mathrm{Zr}(\mathrm{ppm})$ & $\mathrm{Tt}\left({ }^{\circ} \mathrm{C}\right) / 4 \mathrm{GPa}$ & $\mathrm{Tt}\left({ }^{\circ} \mathrm{C}\right) / 2 \mathrm{GPa}$ \\
\hline 07LT6-1-R1 & 0.00 & 0.00 & 0.31 & 100.03 & 0.03 & 0.03 & 0.01 & 100.41 & 67 & 633 & 595 \\
\hline 07LT6-1-R3 & 0.00 & 0.02 & 0.27 & 99.27 & 0.01 & 0.06 & 0.07 & 99.70 & 481 & 799 & 753 \\
\hline 07LT6-1-R2 & 0.00 & 0.02 & 0.32 & 99.21 & 0.02 & 0.05 & 0.03 & 99.66 & 252 & 738 & 695 \\
\hline 07LT6-1-R5 & 0.00 & 0.00 & 0.30 & 99.66 & 0.03 & 0.03 & 0.05 & 100.08 & 363 & 772 & 727 \\
\hline 07LT6-1-R6 & 0.00 & 0.04 & 0.23 & 99.82 & 0.08 & 0.04 & 0.02 & 100.22 & 141 & 690 & 648 \\
\hline 07LT6-1-R7 & 0.00 & 0.02 & 0.23 & 99.41 & 0.05 & 0.04 & 0.02 & 99.77 & 126 & 681 & 640 \\
\hline 07LT6-1A-R1 & 0.00 & 0.00 & 0.29 & 98.23 & 0.06 & 0.04 & 0.05 & 98.66 & 345 & 767 & 723 \\
\hline 07LT6-1A-R2 & 0.00 & 0.00 & 0.21 & 99.35 & 0.10 & 0.02 & 0.03 & 99.71 & 215 & 725 & 682 \\
\hline 07LT6-1A-R3 & 0.00 & 0.00 & 0.43 & 98.90 & 0.05 & 0.04 & 0.03 & 99.44 & 192 & 715 & 673 \\
\hline 07LT6-1A-R4 & 0.00 & 0.00 & 0.35 & 99.26 & 0.03 & 0.04 & 0.01 & 99.69 & 96 & 660 & 620 \\
\hline 07LT6-1A-R5 & 0.00 & 0.00 & 0.30 & 100.52 & 0.03 & 0.03 & 0.10 & 100.97 & 710 & 839 & 792 \\
\hline 07LT6-1A-R6 & 0.00 & 0.02 & 0.15 & 100.81 & 0.21 & 0.05 & 0.07 & 101.30 & 504 & 804 & 758 \\
\hline 07LT6-1A-R7 & 0.00 & 0.00 & 0.21 & 100.35 & 0.07 & 0.11 & 0.11 & 100.85 & 777 & 849 & 801 \\
\hline 07LT6-1-R4 & 0.00 & 0.01 & 0.30 & 101.11 & 0.03 & 0.04 & 0.08 & 101.56 & 561 & 815 & 710 \\
\hline 09LT2-1-R1 & 0.00 & 0.01 & 0.36 & 101.36 & 0.05 & 0.03 & 0.04 & 101.88 & 298 & 754 & 776 \\
\hline 09LT2-1-R2 & 0.00 & 0.01 & 0.50 & 101.52 & 0.03 & 0.07 & 0.08 & 102.20 & 608 & 823 & 625 \\
\hline 09LT2-1-R3 & 0.00 & 0.00 & 0.46 & 100.88 & 0.04 & 0.03 & 0.01 & 101.42 & 102 & 665 & 782 \\
\hline 09LT2-1-R4 & 0.06 & 0.00 & 0.36 & 96.97 & 0.05 & 0.03 & 0.09 & 97.56 & 645 & 829 & 770 \\
\hline 03LT1-1H-R1 & 0.00 & 0.00 & 0.36 & 101.55 & 0.03 & 0.07 & 0.08 & 102.09 & 573 & 817 & 789 \\
\hline 03LT1-1H-R2 & 0.00 & 0.00 & 0.37 & 101.93 & 0.09 & 0.07 & 0.10 & 102.54 & 693 & 837 & 768 \\
\hline 03LT1-1Ru1 & 0.07 & 0.03 & 1.01 & 99.29 & 0.04 & 0.08 & 0.04 & 101.08 & 296 & 753 & 709 \\
\hline 03LT1-1Ru2 & 0.03 & 0.02 & 0.51 & 96.94 & 0.06 & 0.07 & 0.06 & 98.01 & 466 & 796 & 750 \\
\hline 03LT1-1Ru3 & 0.08 & 0.04 & 1.23 & 98.47 & 0.06 & 0.07 & 0.04 & 100.58 & 311 & 758 & 713 \\
\hline 06LT3-2Ru1 & 0.01 & 0.01 & 0.30 & 98.57 & 0.10 & 0.02 & 0.08 & 99.14 & 607 & 823 & 776 \\
\hline 06LT3-2Ru2 & 0.03 & 0.05 & 0.53 & 98.33 & 0.10 & 0.01 & 0.03 & 99.28 & 229 & 730 & 688 \\
\hline
\end{tabular}

Temperatures were calculated using the equation given by Tomkins et al. (2007), the pressures were set to be $4 \mathrm{GPa}$ and $2 \mathrm{GPa}$, respectively. The Zr contents were analyzed by EPMA. 
Table 4 Ti-in-zircon temperatures and zircon U-Pb ages for eclogites from the Luotian dome in the North Dabie complex zone

\begin{tabular}{|c|c|c|c|c|c|c|}
\hline Tyре & $\begin{array}{c}\text { Sample } \\
\text { No. }\end{array}$ & Domain & Nature & $\mathrm{Ti}(\mathrm{ppm})$ & $\mathrm{T}\left({ }^{\circ} \mathrm{C}\right)$ & $\begin{array}{l}{ }^{206} \mathrm{~Pb} /{ }^{238} \mathrm{U} \\
\text { Age (Ma) }\end{array}$ \\
\hline & $03 L T 1-1$ & & & & & \\
\hline & 03LT1-1-1-1 & $\mathrm{m}$ & me & 3.4 & 654 & $226 \pm 4$ \\
\hline & 03LT1-1-3-1 & $\mathrm{m}$ & me & 3.6 & 659 & $231 \pm 4$ \\
\hline & 03LT1-1-8-1 & $\mathrm{m}$ & me & 4.8 & 680 & $224 \pm 3$ \\
\hline & 03LT1-1-10-1 & $\mathrm{m}$ & me & 3.1 & 647 & $216 \pm 3$ \\
\hline & 03LT1-1-17-1 & $\mathrm{m}$ & me & 4.4 & 673 & $217 \pm 4$ \\
\hline & 03LT1-1-16-1 & $\mathrm{m}$ & me & 3.4 & 654 & $234 \pm 3$ \\
\hline & 03LT1-1-18-1 & $\mathrm{m}$ & me & 2.2 & 622 & $217 \pm 4$ \\
\hline & 03LT1-1-20-1 & $\mathrm{m}$ & me & 8.5 & 726 & $225 \pm 3$ \\
\hline & 03LT1-1-22-1 & $\mathrm{m}$ & me & 4.7 & 678 & $229 \pm 3$ \\
\hline & 03LT1-1-26-1 & $\mathrm{m}$ & me & 4 & 667 & $213 \pm 3$ \\
\hline \multirow[t]{27}{*}{ Type 1} & 03LT1-1-24-1 & $\mathrm{m}$ & me & 26.9 & 836 & $220 \pm 3$ \\
\hline & $06 L T 3-2$ & & & & & \\
\hline & 06LT3-2-1-1 & $r$ & me & 4.6 & 678 & $180 \pm 12$ \\
\hline & 06LT3-2-3-1 & $r$ & me & 3.4 & 653 & $191 \pm 10$ \\
\hline & 06LT3-2-7-1 & $\mathrm{m}$ & me & 2.9 & 643 & $220 \pm 3$ \\
\hline & 06LT3-2-6-1 & $\mathrm{m}$ & me & 63.1 & 934 & $225 \pm 14$ \\
\hline & 06LT3-2-11-1 & $\mathrm{m}$ & me & 6.8 & 709 & $207 \pm 5$ \\
\hline & 06LT3-2-15-1 & $\mathrm{m}$ & me & 13.9 & 771 & $230 \pm 25$ \\
\hline & 06LT3-2-18-1 & $\mathrm{m}$ & me & 20.3 & 807 & $215 \pm 18$ \\
\hline & 06LT3-2-19-1 & $\mathrm{m}$ & me & 97.8 & 991 & $211 \pm 3$ \\
\hline & 06LT3-2-21-1 & $r$ & me & 25 & 828 & $207 \pm 4$ \\
\hline & 06LT3-2-20-1 & $r$ & me & 16.2 & 785 & $200 \pm 18$ \\
\hline & 07LT6-1 & & & & & \\
\hline & 07LT6-1-1-1 & $\mathrm{m}$ & me & 4.8 & 680 & $221 \pm 6$ \\
\hline & 07LT6-1-3-1 & $\mathrm{m}$ & me & 5.2 & 688 & $225 \pm 5$ \\
\hline & 07LT6-1-5-1 & $\mathrm{r}$ & me & 3.1 & 647 & $189 \pm 6$ \\
\hline & 07LT6-1-8-2 & $\mathrm{m}$ & me & 20.5 & 808 & $218 \pm 5$ \\
\hline & 07LT6-1-9-1 & $\mathrm{r}$ & me & 3.3 & 652 & $197 \pm 5$ \\
\hline & 07LT6-1-10-2 & $\mathrm{m}$ & me & 4 & 667 & $227 \pm 5$ \\
\hline & 07LT6-1-17-1 & $r$ & me & 3.3 & 652 & $208 \pm 6$ \\
\hline & 07LT6-1-13-1 & $\mathrm{m}$ & me & 66.3 & 940 & $218 \pm 5$ \\
\hline & 07LT6-1-15-1 & $\mathrm{m}$ & me & 2.9 & 644 & $238 \pm 7$ \\
\hline & 07LT6-1-14-1 & $\mathrm{m}$ & me & 3.2 & 649 & $215 \pm 7$ \\
\hline & 07LT6-1-16-1 & $\mathrm{m}$ & me & 2.4 & 630 & $225 \pm 5$ \\
\hline & LT10 & & & & & \\
\hline & LT10-2-1 & c & ma & 6.9 & 709 & $783 \pm 13$ \\
\hline & LT10-2-2 & c & ma & 8.8 & 730 & $737 \pm 15$ \\
\hline
\end{tabular}




\begin{tabular}{|c|c|c|c|c|c|c|}
\hline & LT10-3-2 & C & me & 6.4 & 703 & $822 \pm 17$ \\
\hline & LT10-4-1 & C & ma & 7.7 & 718 & $638 \pm 11$ \\
\hline & LT10-1-1 & c & me & 274 & 1149 & $788 \pm 13$ \\
\hline & LT10-1-2 & c & me & 9.3 & 734 & $766 \pm 13$ \\
\hline & LT10-4-2 & C & me & 4.3 & 672 & $788 \pm 14$ \\
\hline \multirow[t]{18}{*}{ Type 2} & LT10-3-5 & C & ma & 47.2 & 898 & $799 \pm 15$ \\
\hline & LT10-3-9 & C & ma & 6.3 & 702 & $642 \pm 14$ \\
\hline & LT10-1-4 & c & me & 48.5 & 902 & $791 \pm 13$ \\
\hline & LT10-4-5 & c & ma & 14.1 & 772 & $798 \pm 16$ \\
\hline & LT10-4-4 & c & ma & 17.7 & 794 & $784 \pm 16$ \\
\hline & LT10-4-7 & c & ma & 6.3 & 702 & $791 \pm 16$ \\
\hline & LT10-4-3 & C & me & 12.6 & 762 & $335 \pm 7$ \\
\hline & LT10-1-8 & c & me & 21.4 & 812 & $783 \pm 13$ \\
\hline & LT10-1-11 & c & me & 5.5 & 691 & $799 \pm 14$ \\
\hline & LT10-1-9 & c & me & 33.7 & 860 & $730 \pm 12$ \\
\hline & LT10-3-6 & c & me & 6 & 698 & $696 \pm 14$ \\
\hline & LT10-3-7 & c & me & 11.5 & 753 & $726 \pm 15$ \\
\hline & LT9 & & & & & \\
\hline & LT9-2-1 & C & ma & 17.6 & 793 & $802 \pm 16$ \\
\hline & LT9-3-1 & C & me & 236.1 & 1124 & $830 \pm 18$ \\
\hline & LT9-2-2 & c & ma & 136.2 & 1038 & $736 \pm 14$ \\
\hline & LT9-1-6 & c & me & 94.4 & 986 & $375 \pm 6$ \\
\hline & LT9-1-7 & c & me & 68.8 & 945 & $707 \pm 12$ \\
\hline
\end{tabular}

Notes: c, core; m, mantle; r, rim; ma, magmatic; me, metamorphic. Temperatures were calculated by Watson et al. (2006). The Ti contents in zircons were analyzed by LA-MC-ICPMS. 


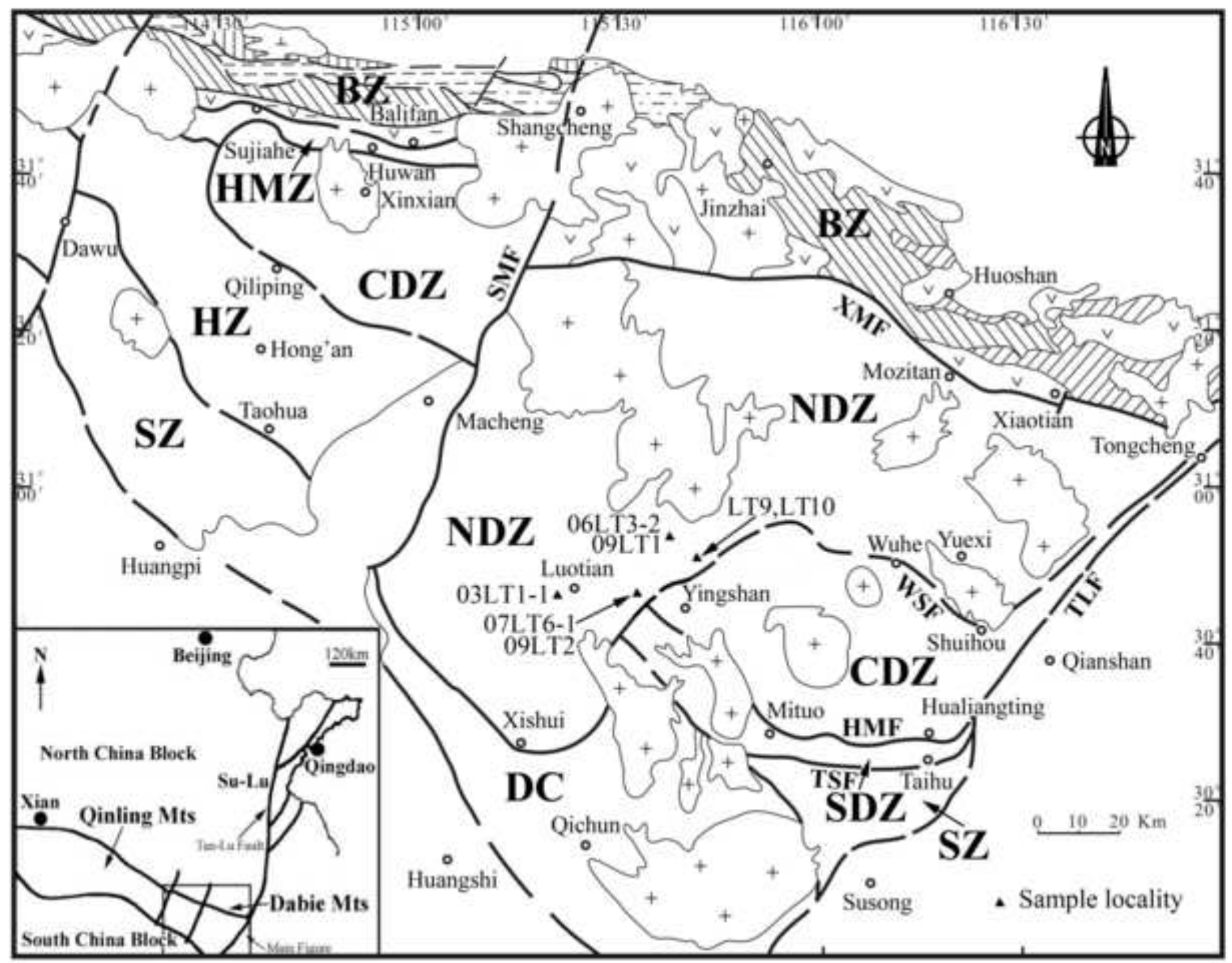

VV Mesonoic volcanics

++ Mesozois granihoid $+\perp$ Palsoonoic dionite

$\checkmark$ - Dingyuan melavolcanics

[2] Meishan coal series

IIII] Erlansping Group

MV Metu-flysch

E-Guishan Formation

VD Lurhenguan complex

A Fault/Geological boundary 

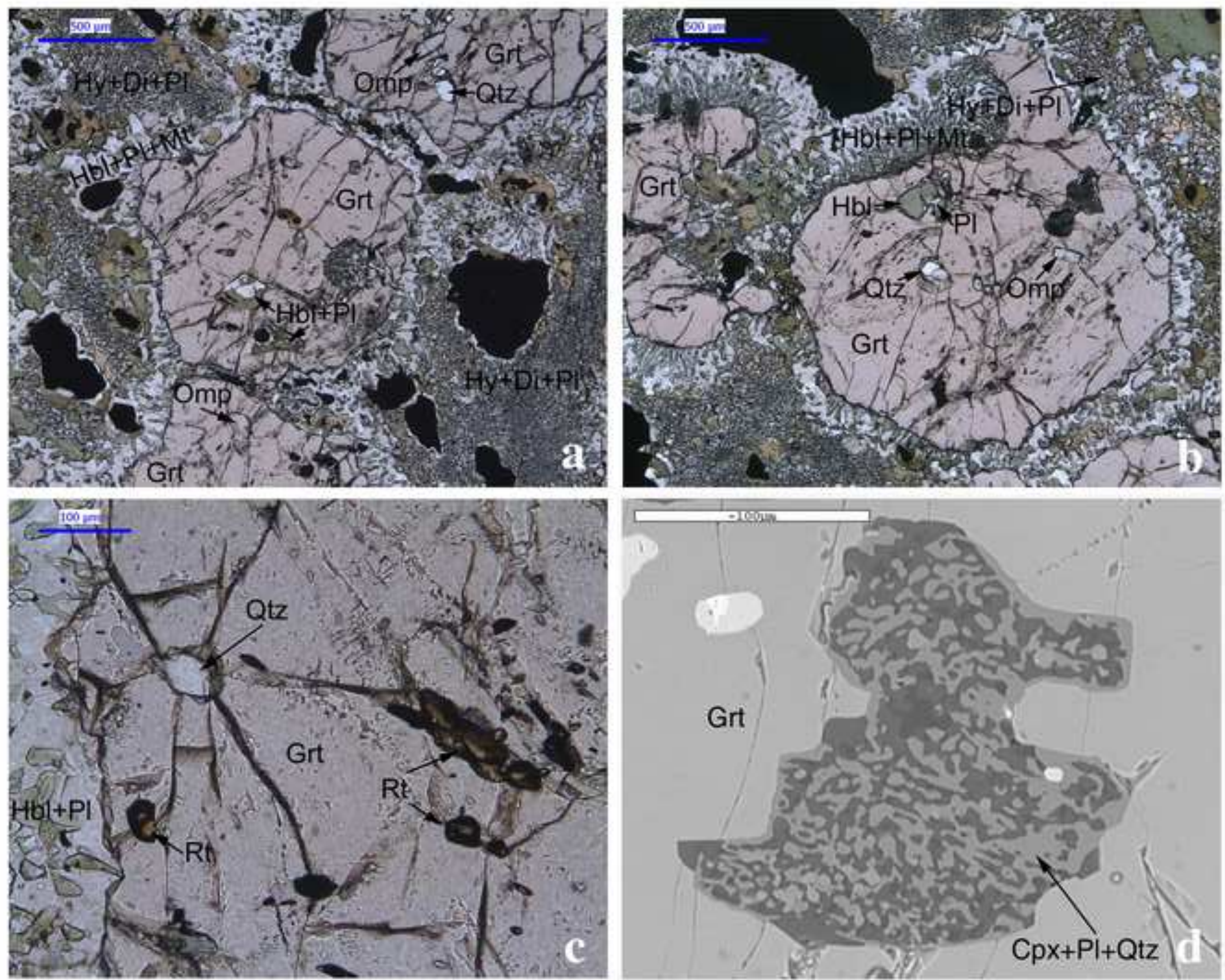
Click here to download high resolution image
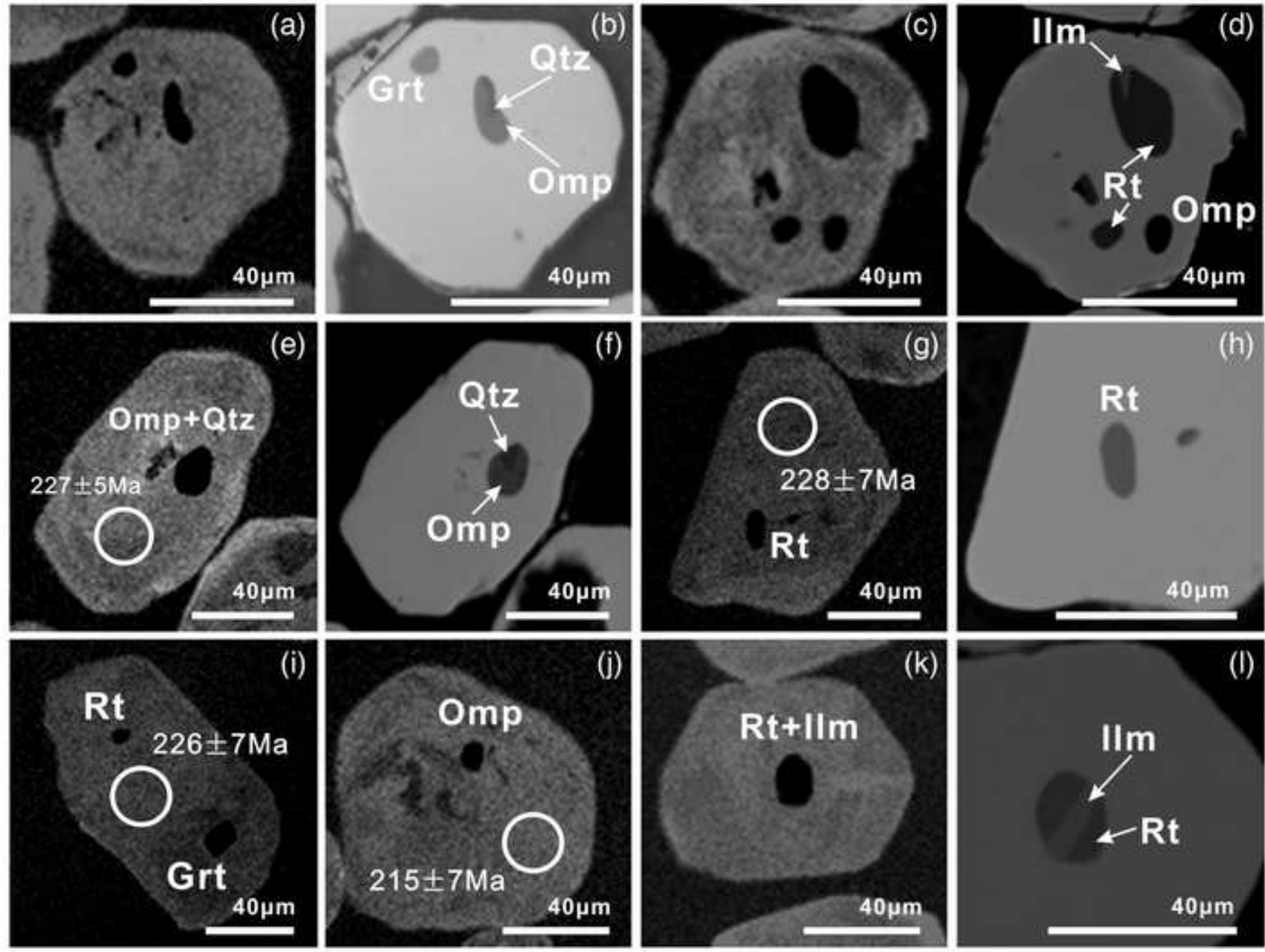

$40 \mu \mathrm{m}$ 


\section{WEF}
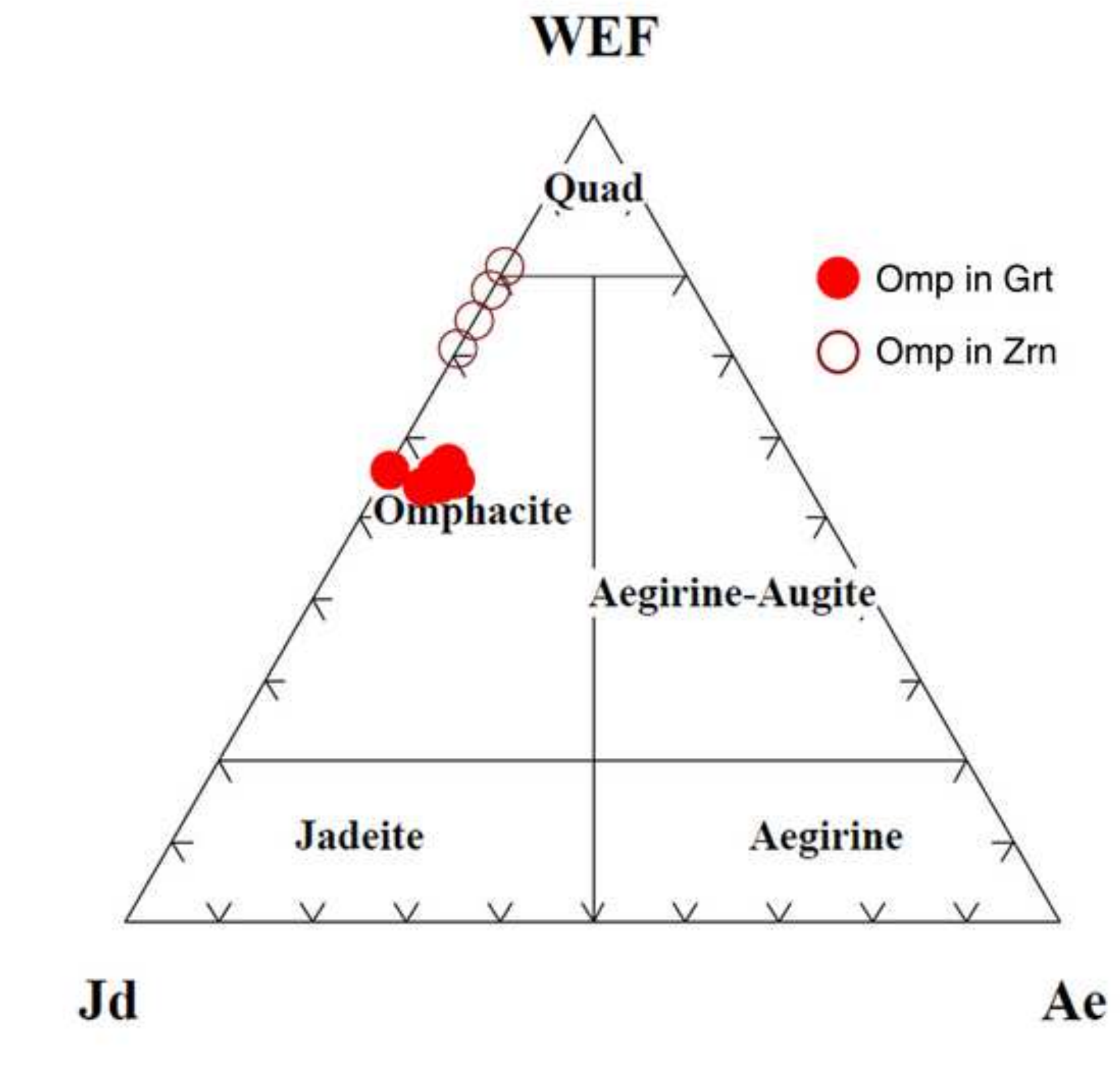

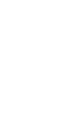

$\mathbf{J d}$
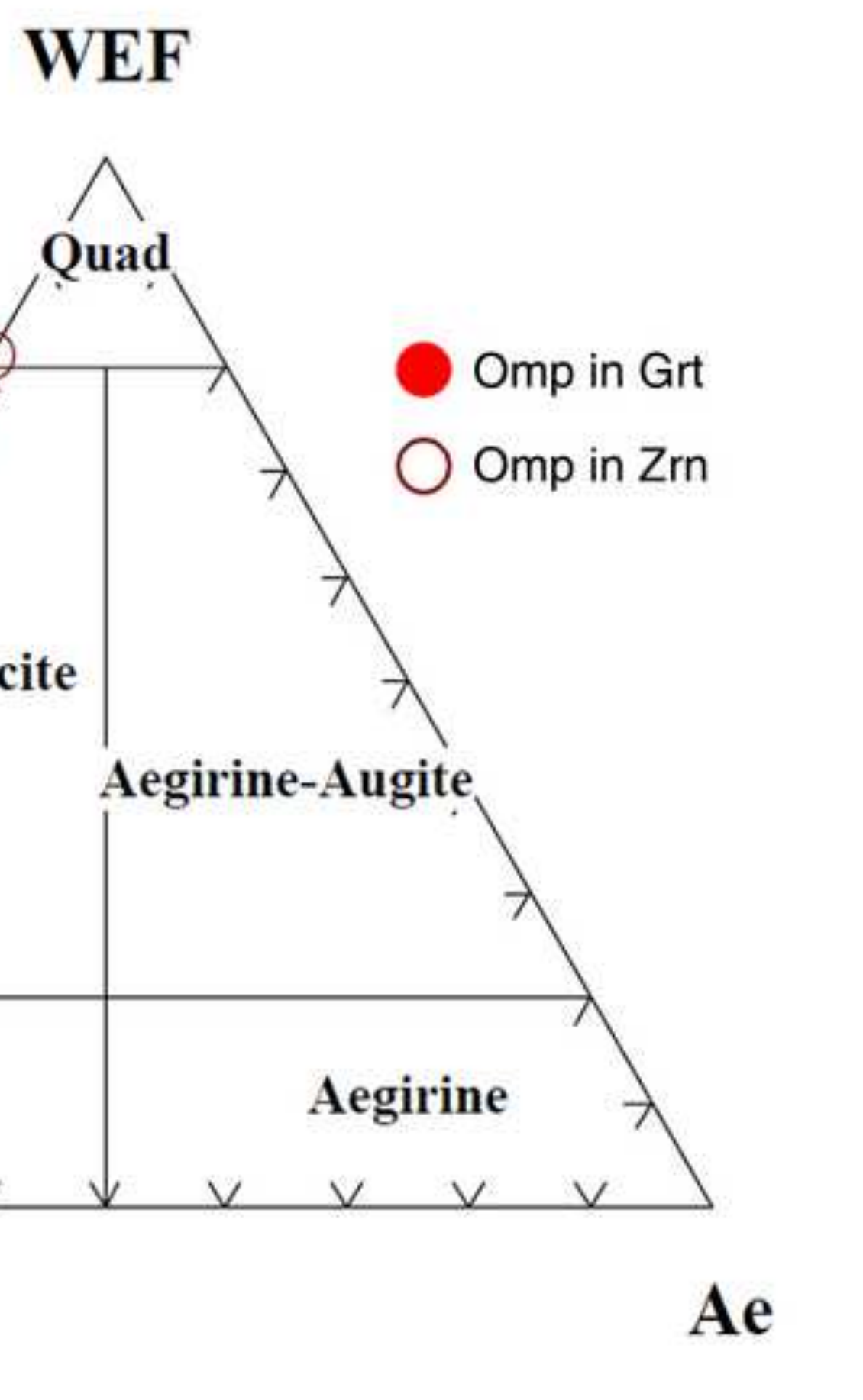
Click here to download high resolution image
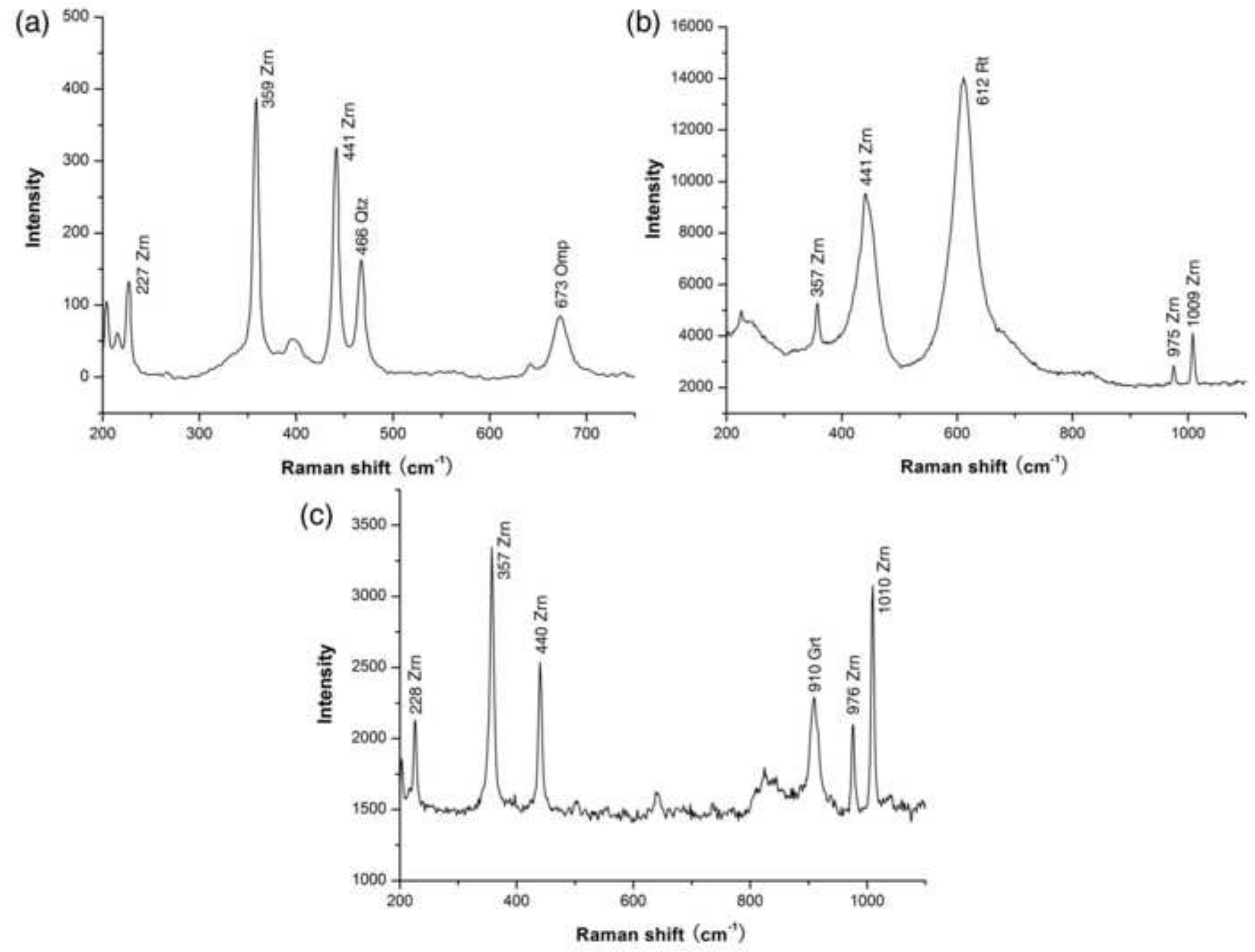


\section{Figure 6}

Click here to download high resolution image

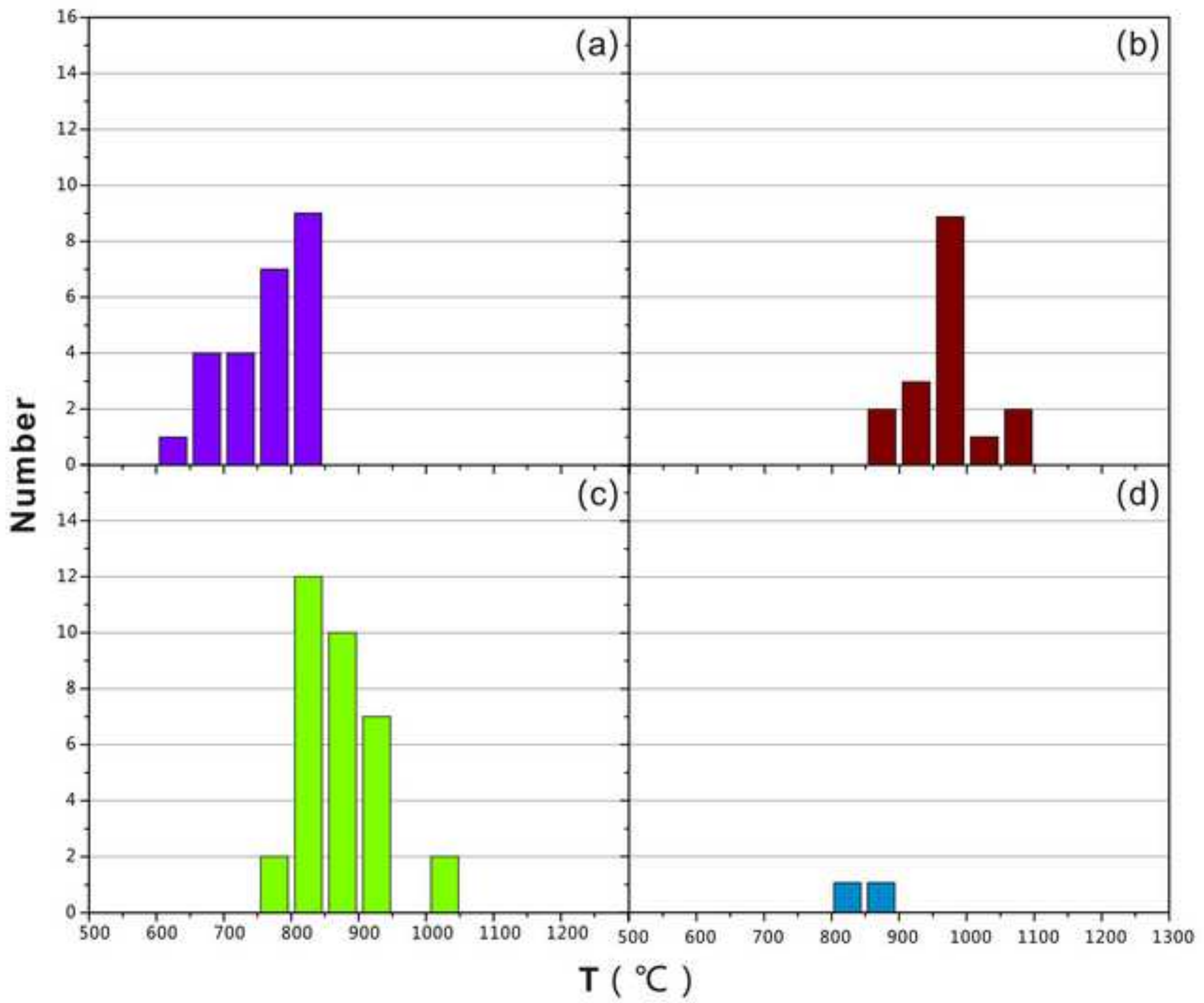




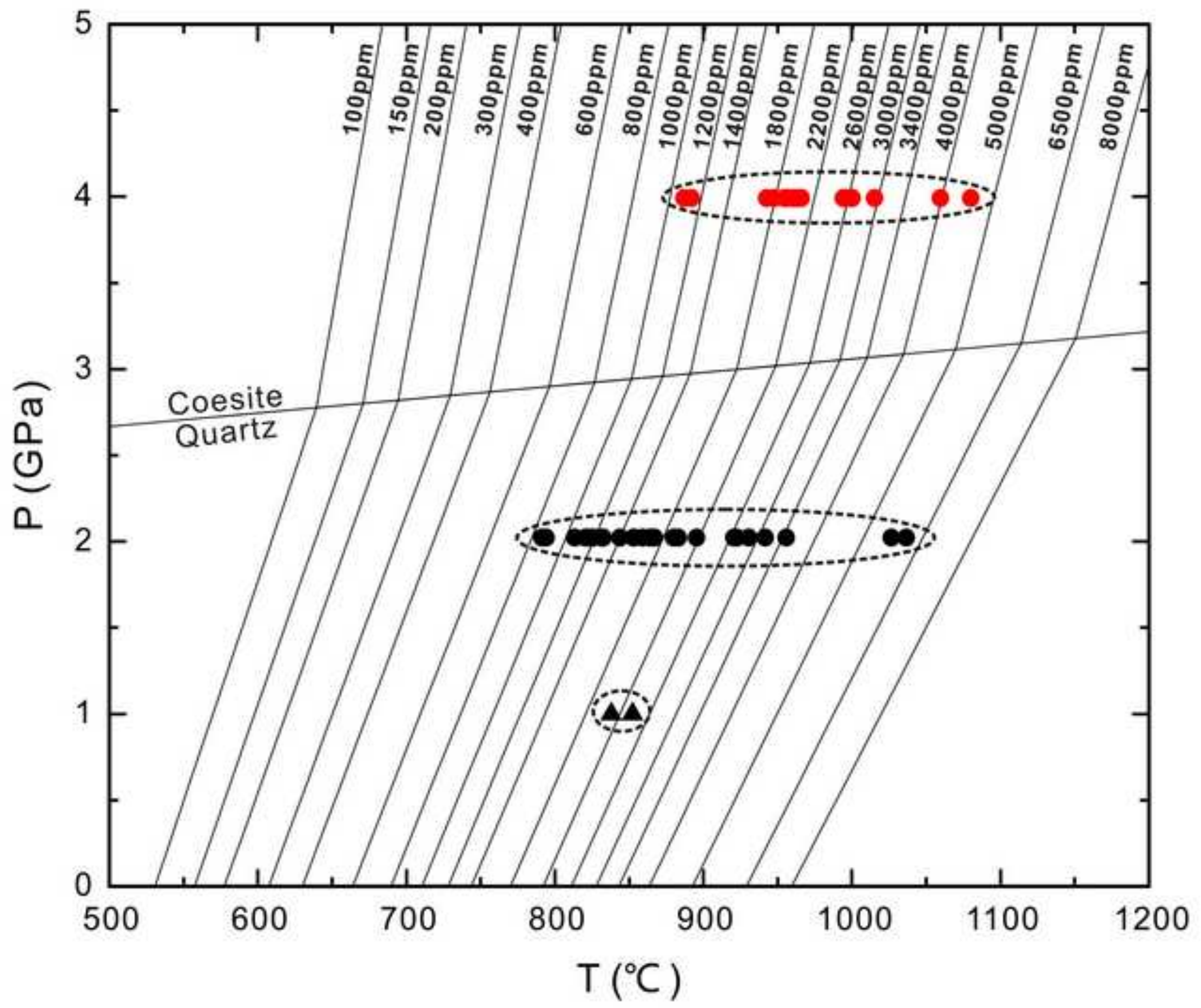




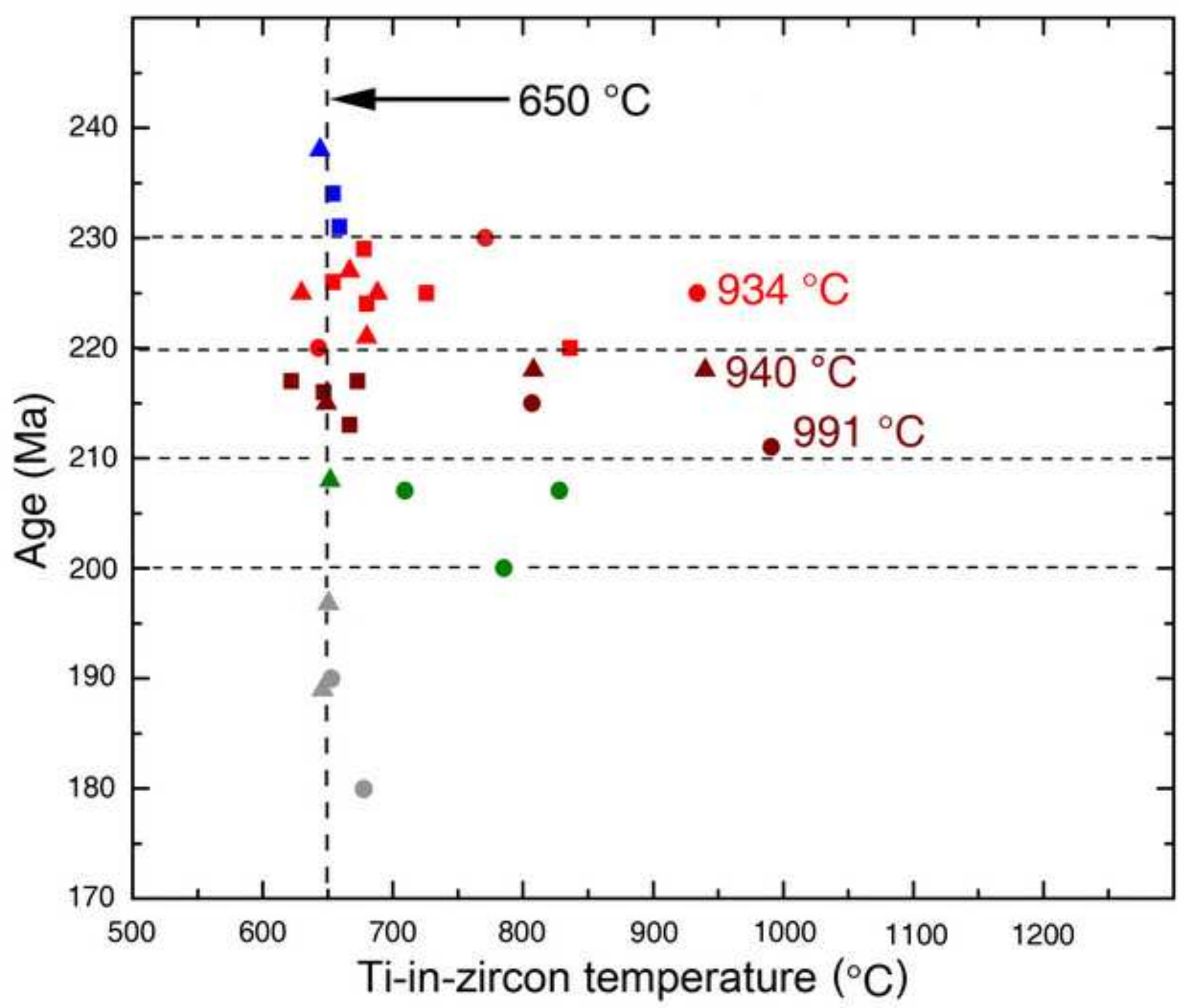




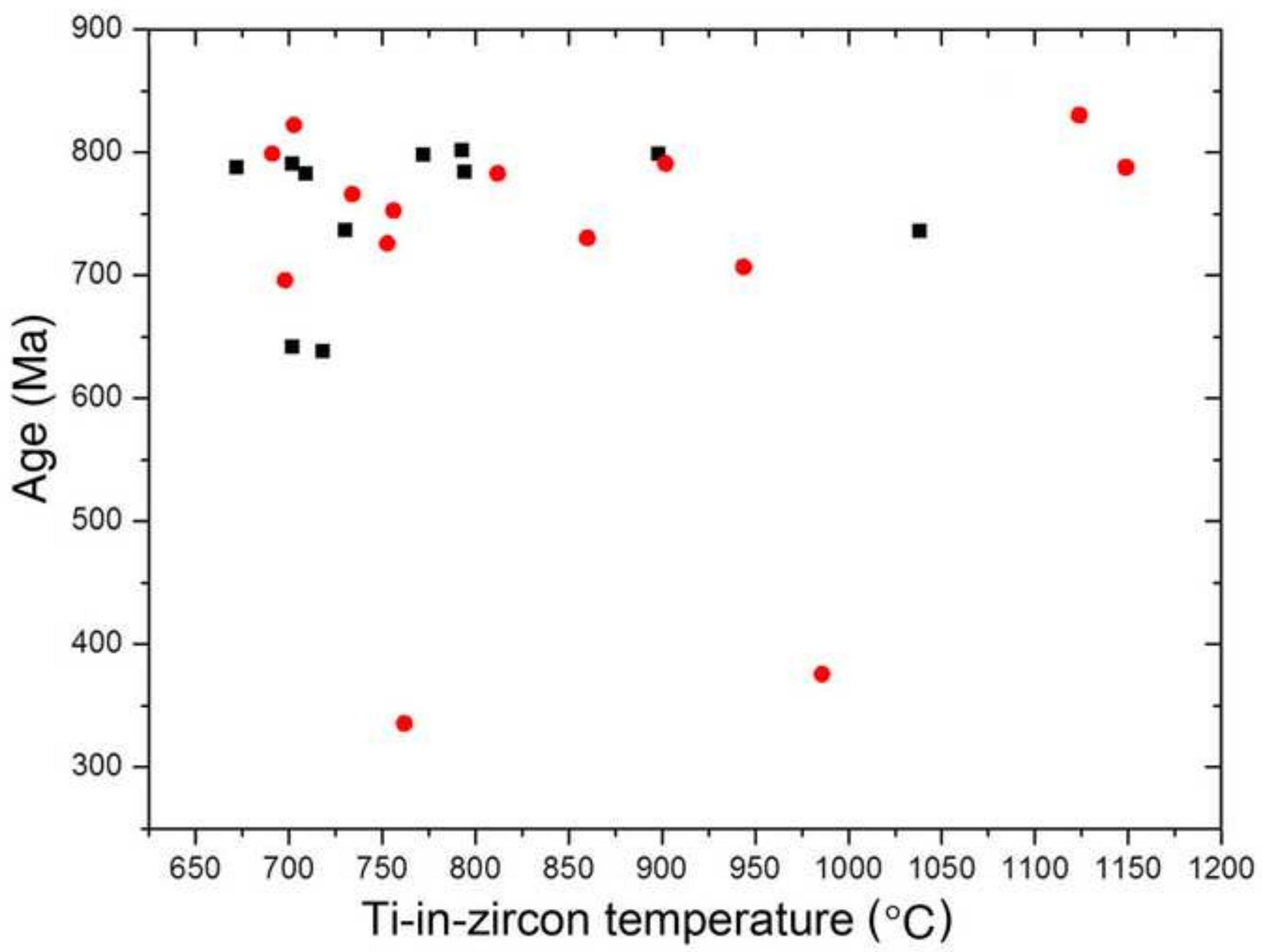




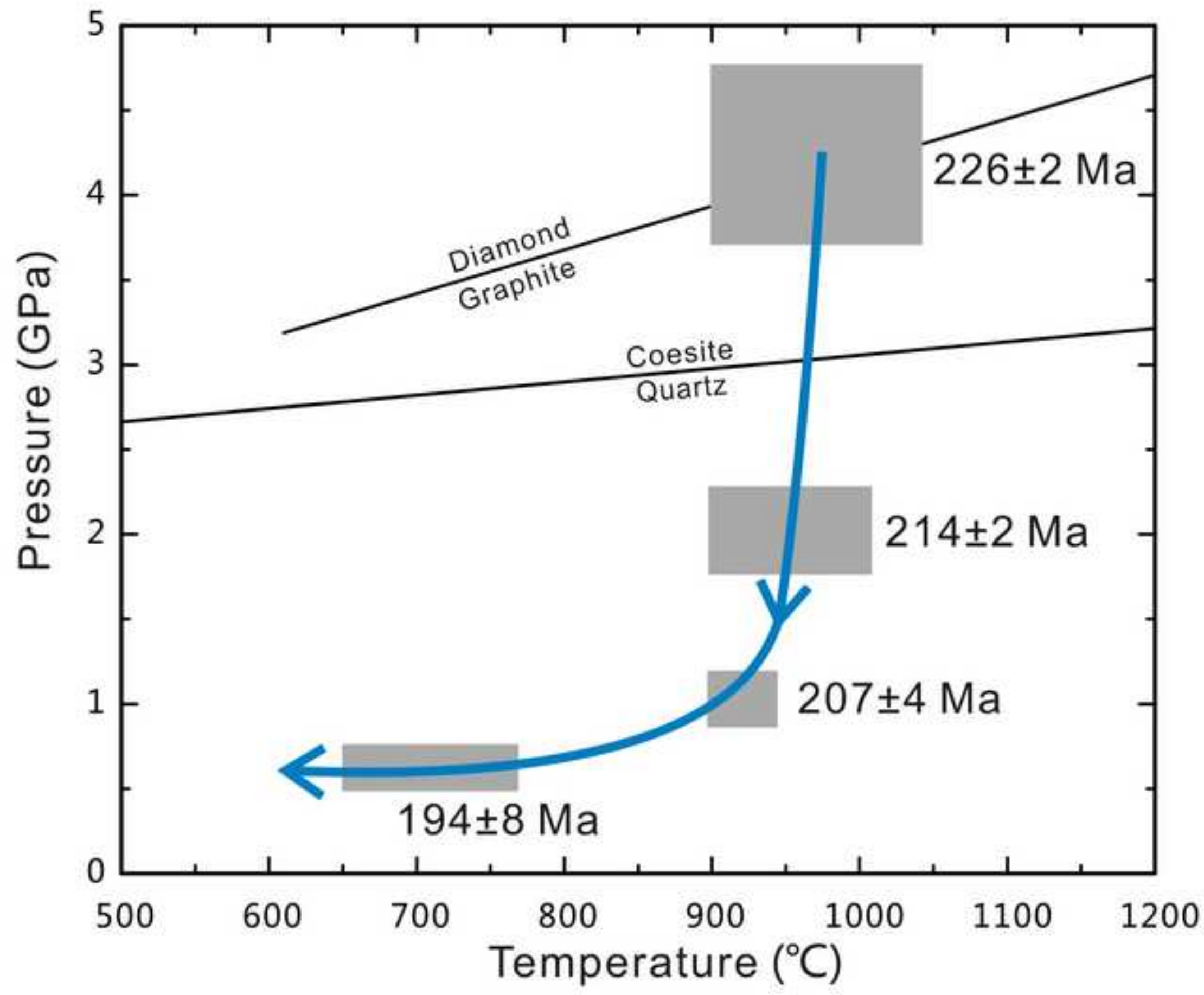

